\title{
Transgenic Overexpression of the Disordered Prion Protein N1 Fragment in Mice Does Not Protect Against Neurodegenerative Diseases Due to Impaired ER Translocation
}

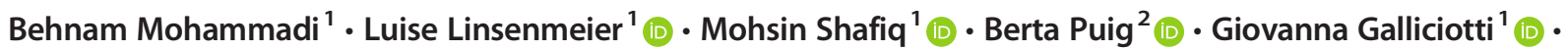 \\ Camilla Giudici $^{3}$ - Michael Willem ${ }^{3}$. Thomas Eden ${ }^{4}$. Friedrich Koch-Nolte ${ }^{4}$ (D) Yu-Hsuan Lin $^{5} \cdot$ Jörg Tatzelt $^{5}$ (D) \\ Markus Glatzel ${ }^{1}$ (D) Hermann C. Altmeppen ${ }^{1}$ (D)
}

Received: 26 September 2019 / Accepted: 7 April 2020 / Published online: 4 May 2020

(C) The Author(s) 2020

\begin{abstract}
The structurally disordered $\mathrm{N}$-terminal half of the prion protein $\left(\mathrm{PrP}^{\mathrm{C}}\right)$ is constitutively released into the extracellular space by an endogenous proteolytic cleavage event. Once liberated, this N1 fragment acts neuroprotective in ischemic conditions and interferes with toxic peptides associated with neurodegenerative diseases, such as amyloid-beta (A $\beta$ ) in Alzheimer's disease. Since analog protective effects of N1 in prion diseases, such as Creutzfeldt-Jakob disease, have not been studied, and given that the protease releasing N1 has not been identified to date, we have generated and characterized transgenic mice overexpressing N1 (TgN1). Upon intracerebral inoculation of TgN1 mice with prions, no protective effects were observed at the levels of survival, clinical course, neuropathological, or molecular assessment. Likewise, primary neurons of these mice did not show protection against $A \beta$ toxicity. Our biochemical and morphological analyses revealed that this lack of protective effects is seemingly due to an impaired ER translocation of the disordered N1 resulting in its cytosolic retention with an uncleaved signal peptide. Thus, TgN1 mice represent the first animal model to prove the inefficient ER translocation of intrinsically disordered domains (IDD). In contrast to earlier studies, our data challenge roles of cytoplasmic N1 as a cell penetrating peptide or as a potent "anti-prion" agent. Lastly, our study highlights both the importance of structured domains in the nascent chain for proteins to be translocated and aspects to be considered when devising novel N1-based therapeutic approaches against neurodegenerative diseases.
\end{abstract}

Keywords Cell-penetrating peptide $\cdot$ Cytosolic prions · Intrinsically disordered domains · Prion disease $\cdot$ Proteasome Translocation

Electronic supplementary material The online version of this article (https://doi.org/10.1007/s12035-020-01917-2) contains supplementary material, which is available to authorized users.

Hermann C. Altmeppen

h.altmeppen@uke.de

1 Institute of Neuropathology, University Medical Center Hamburg-Eppendorf (UKE), Hamburg, Germany

2 Department of Neurology, Experimental Research in Stroke and Inflammation (ERSI), University Medical Center Hamburg-Eppendorf, Hamburg, Germany

3 Biomedical Center (BMC), Faculty of Medicine, Ludwig-Maximilians-University, Munich, Germany

4 Institute of Immunology, University Medical Center Hamburg-Eppendorf (UKE), Hamburg, Germany

5 Institute of Biochemistry and Pathobiochemistry, Biochemistry of Neurodegenerative Diseases, Ruhr University Bochum, Bochum, Germany

\section{Abbreviations}

A $\beta \quad$ amyloid-beta peptide

AD Alzheimer's disease

CPP cell-penetrating peptide

GPI glycosylphosphatidylinositol (anchor)

IDD intrinsically disordered domain

IDP intrinsically disordered protein/peptide

N1 prion protein N-terminal fragment

PD Parkinson's disease

$\mathrm{PrP}^{\mathrm{C}} \quad$ cellular prion protein

$\mathrm{PrP}^{\mathrm{Sc}}$ pathogenic isoform of the prion protein

SP signal peptide

UPS ubiquitin-proteasome system

\section{Introduction}

The prion protein $\left(\mathrm{PrP}^{\mathrm{C}}\right)$, a glycoprotein with high expression levels and biological relevance in the nervous system, is 
composed of two structurally very dissimilar parts [1-3]. Its globular C-terminal half contains structure-lending elements, such as $\alpha$-helices, $\beta$-sheets, a disulfide bond, up to two $\mathrm{N}$ glycans, and a GPI-anchor for cell surface attachment [4]. In contrast, the N-terminal half of the molecule is highly flexible and lacks structural features [5], thus representing a prototype of so-called intrinsically disordered domains/proteins (IDD/ IDP, Fig. 1) [6]. Although such IDDs inherently miss folded parts as preformed "binding interfaces", they are nevertheless able to initiate transient high-affinity interactions with other proteins [7]. In fact, the N-terminal half of $\operatorname{PrP}^{\mathrm{C}}$ plays key roles for the physiological functions and pathological roles of this protein. As part of the membrane-bound full-length $\mathrm{PrP}^{\mathrm{C}}$, the N-terminal half is considered as a flexible molecular sensor of the extracellular milieu [8] that may transiently adopt a particular shape upon binding of specific ligands [9]. Several of those interacting ligands have been described, among them divalent cations as well as various proteins/ peptides of physiological or pathological relevance [8, 10-13]. Such interactions, for instance, regulate the cellular trafficking and surface homeostasis of $\operatorname{PrP}^{\mathrm{C}}$ [10, 14-19]. Of note, the $\mathrm{N}$-terminal part is also critical for the initial

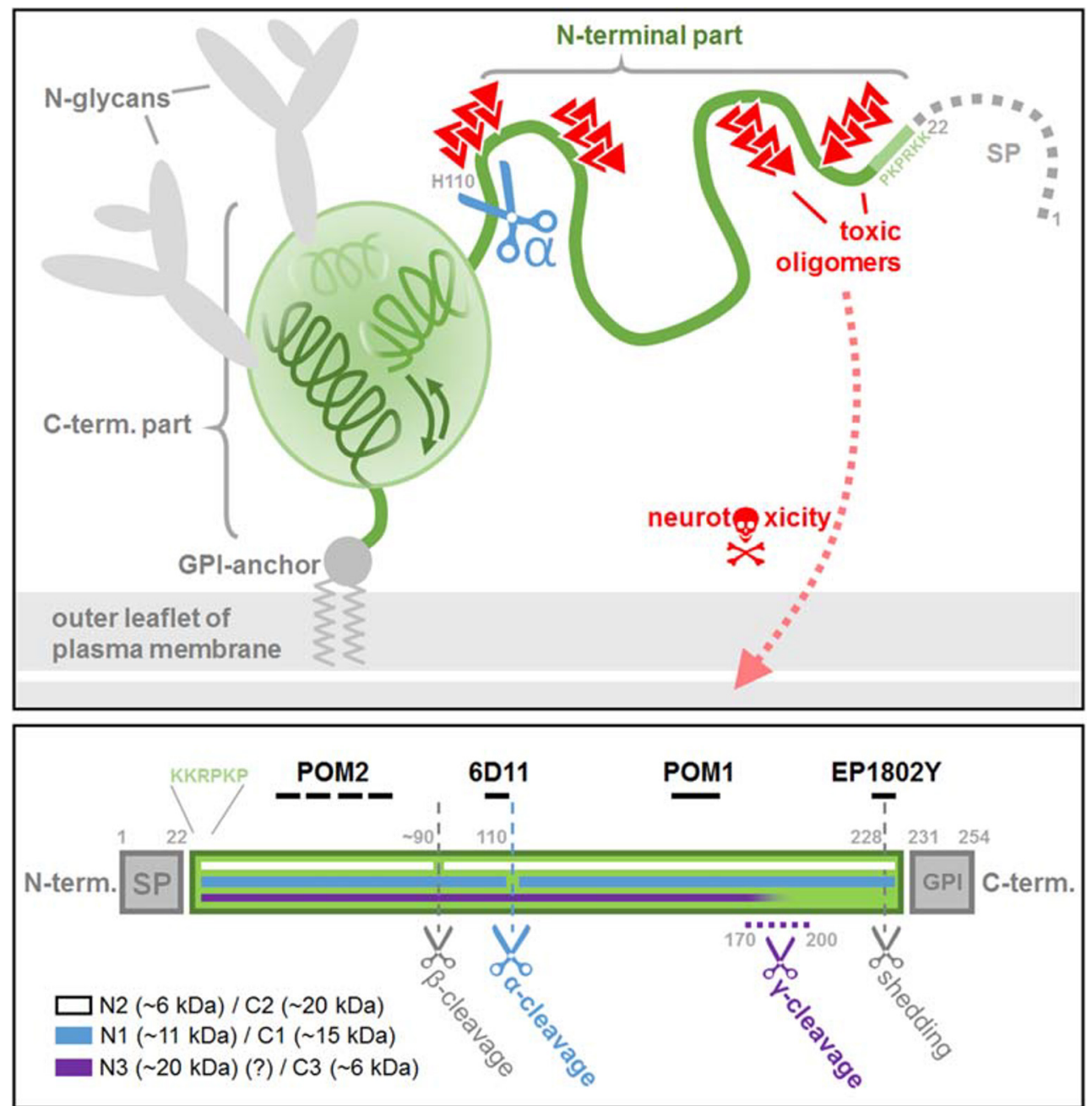

Fig. 1 Upper panel: schematic representation of the prion protein. The cellular prion protein $\left(\mathrm{PrP}^{\mathrm{C}}\right)$ is composed of two structurally different parts. The rather globular shaped $\mathrm{C}$-terminal half contains three $\alpha$-helices, a short $\beta$-sheet, a disulfide bridge (not shown), up to two $\mathrm{N}$-glycans and a GPI-anchor for attachment to the outer leaflet of the plasma membrane. The N-terminal half is largely unstructured and qualifies as an intrinsically disordered domain (IDD). However, this part contains important binding sites for interaction with various molecules, including toxic protein oligomers and proteopathic seeds (red) found in neurodegenerative diseases. Binding of the latter to membrane-bound $\operatorname{PrP}^{C}$ induces neurotoxic signaling events and may lead to pore formation via insertion of the $\mathrm{N}$ terminus into the membrane. A conserved proteolytic cleavage event termed $\alpha$-cleavage (blue scissors) at H110 separates the two dissimilar halves of $\operatorname{PrP}^{\mathrm{C}}$ and releases the disordered N1 fragment into the extracellular space, where it exerts neuroprotective effects. Note that the Nterminal ER targeting signal peptide (SP; dotted gray stretch) is not part of mature $\mathrm{PrP}^{\mathrm{C}}$ under physiological conditions. Lower panel: linear representation of the $\operatorname{PrP}^{\mathrm{C}}$ sequence accentuating (i) known (proteolytic) cleavage events, (ii) resulting $\mathrm{N}$ - and $\mathrm{C}$-terminal fragments (respective expected molecular weights), and (iii) (approximated) position of epitopes described for $\operatorname{PrP}^{\mathrm{C}}$-directed antibodies (black) used in this study. Note that antibody $6 \mathrm{D} 11$ can be instrumental to differentiate between $\mathrm{N}$ terminal fragments resulting from the $\alpha$ - (detection of N1) and $\beta$ cleavage (no detection of N2). GPI = position of GPI-anchor signal sequence 
interaction between $\operatorname{PrP}^{\mathrm{C}}$ and aggregates ("seeds") of its pathological isoform $\left(\mathrm{PrP}^{\mathrm{Sc}}\right)[8,20-25]$ and, hence, for the progressive templated misfolding process underlying fatal and transmissible prion diseases in humans (e.g., Creutzfeldt-Jakob disease) and animals (e.g., Scrapie of sheep, BSE in cattle) [26-28]. In these diseases, the N-terminal domain within $\mathrm{PrP}^{\mathrm{C}}$ also fulfills "toxic effector" functions $[3,29,30]$. It is conceivable that this is due to interactions of this part with the plasma membrane and subsequent pore formation therein $[3,31,32]$. This, in turn, might be linked to the very $\mathrm{N}$-terminal sequence qualifying as a cell-penetrating peptide (CPP) [33-35]. Moreover, $\operatorname{PrP}^{\mathrm{C}}$ at the neuronal surface is a receptor for other toxic oligomeric proteins abundantly produced in other neurodegenerative diseases, such as Alzheimer's (AD) or Parkinson's disease (PD). Again, it is the N-terminal part of $\operatorname{PrP}^{\mathrm{C}}$ that acts as the crucial docking hub for $\beta$-sheet-rich oligomeric amyloid- $\beta(A \beta)$ peptides and hyperphosphorylated tau (pTau) in $\mathrm{AD}$ or $\alpha$-synuclein in PD, thus allowing for highaffinity binding and subsequent neurotoxic signaling via additional $\mathrm{PrP}^{\mathrm{C}}$ interacting transmembrane proteins (Fig. 1) [9, 36-45].

Interestingly, the $\mathrm{N}$-terminal half can be cleaved off from the protein and is then released into the extracellular space as a soluble N1 fragment in a physiological proteolytic process termed $\alpha$-cleavage (Fig. 1) [46-48]. This cleavage is evolutionary conserved, occurs constitutively on a considerable fraction of $\mathrm{PrP}^{\mathrm{C}}$ molecules depending on tissue and cell type, and seems to take place while traversing the secretory pathway or in an endocytic compartment [49]. Biological relevance of this cleavage is supported by the fact that deletions in the $\alpha$-cleavage region result in severe neurotoxicity in respective transgenic mouse models [50-55]. Fittingly, the $\alpha$ cleavage has so far mostly been linked with protective effects [56-60]. As a soluble ligand, N1 acts beneficial in several ways as it reduces hypoxia-induced neuronal damage [61] and may be involved in myelin maintenance [62] and intercellular communication (reviewed in [63]). With regard to $\mathrm{AD}$, numerous studies have shown that exogenously administered N1 and N1-like peptides are able to block toxic $A \beta$ oligomers and interfere with their synaptic impairment and neurotoxicity [38, 64-71].

For prion diseases, however, insight into a potential protective role of $\mathrm{N} 1$ by similarly neutralizing $\mathrm{PrP}^{\mathrm{Sc}}$ oligomers is lacking to date. In addition, the responsible protease (termed $\alpha$ PrPase) [72] for the endogenous generation of $\mathrm{N} 1$ has not been identified unequivocally to date [73, 74], thus precluding direct pharmacological manipulation. We therefore decided to address this issue in vivo by generating transgenic mice overexpressing N1 and challenging them with prions. Such a mouse model has previously been predicted to be of "crucial importance" to assess the therapeutic potential of $\mathrm{N} 1$ in neurodegenerative conditions [75]. While our "protective" strategy eventually failed due to impaired secretion of transgenic
N1, our study (i) provides the first proof of the recently described inefficient translocation of IDDs [6] in an animal model. Moreover, it (ii) challenges both, toxic CPP-like and protective antiprion effects of cytosolic $\mathrm{N} 1$ with uncleaved signal peptides (N1-SP), (iii) questions a relevant role of cytosolic prions in prion diseases, and (iv) highlights important aspects to be considered when investigating the $\alpha$-cleavage of $\operatorname{PrP}^{\mathrm{C}}$ or devising N1-based therapeutic approaches in the future.

\section{Material and Methods}

\section{Plasmids}

To generate the N1-coding plasmid, the construct containing the mouse Prnp open reading frame in pcDNA3.1(-)/Zeo expression vector was used to insert a stop codon after H110 of murine PrP using the QuickChange Site-Directed Mutagenesis Kit (Agilent Technologies). For the N1Fc construct, the pFUSE-mIgG1-Fc1 vector (InvivoGen) was purchased and the sequence coding for amino acids (aa) $1-110$ of $\mathrm{mPrP}$ was subcloned into that preceding the hinge region and the $\mathrm{CH} 2$ and $\mathrm{CH} 3$ domains of the IgG heavy chain. For generating the $\mathrm{N} 1 \mathrm{Nb}$, the cDNA coding for aa $23-110$ of $\mathrm{mPrP}$ was genetically fused to the $\mathrm{N}$-terminus of nanobody $1-10$ e via a 5 GS linkage region and subcloned into the pCSE2.5 expression vector [76] (kindly provided by Dr. Thomas Schirrmann, Braunschweig, Germany) containing an IgKappa leader $\mathrm{N}$-terminal of the $\mathrm{N} 1 \mathrm{Nb}$ construct and a His/Myc tag at the C-terminus. Primers are listed in Suppl. Table 1B.

\section{Generation of TgN1 Mice}

To generate mice overexpressing the N1 fragment, a stop codon was inserted into the murine Prnp sequence (resulting in a stop after H110) in the half-genomic expression vector (mPrPHGC [77]) using the QuickChange II XL SiteDirected Mutagenesis Kit. Before pronuclear injection, the resulting N1mPrPHGC vector was cut with SalI and NotI to remove the pBlue-script sequence. The pronuclear injection into C57BL/6J mice was performed at the Transgenic Mouse Facility (ZMNH, UKE, Hamburg). Positive heterozygous animals were selected by genotyping. All primers are listed in Suppl. Table 1B.

\section{Prion Inoculations}

Intracerebral inoculations of TgN1 mice and WT littermates with prions were performed under deep anesthesia with ketamine and xylazine hydrochloride. In brief, 10-11week-old TgN1 mice $(n=10)$ and littermate controls $(n=$ 9) were inoculated with $30 \mu \mathrm{L}$ of a $1 \%$ homogenate of 
Rocky Mountain Laboratory (RML) prions (RML 5.0 inoculum, corresponding to $3 \times 10^{5} \mathrm{LD} 50$ ) into the forebrain. After inoculation, to minimize suffering of the animals, careful observation and special treatment (such as incubation on a warming plate and administration of wet food) were applied until initial recovery. Mice were then checked daily and observation was intensified upon appearance of first clinical signs of prion disease. All mice were sacrificed and analyzed when they reached fully established prion disease. Additionally, we performed mock inoculations with $30 \mu \mathrm{L}$ of a $1 \%$ brain homogenate from uninfected CD1 mice into age-matched $\operatorname{TgN} 1(n=5)$ and littermate controls $(n=4)$. These animals were sacrificed at 240 days post-inoculation (dpi) lacking any clinical signs.

\section{Primary Neuronal Cultures}

\section{Monocultures}

Primary neurons were prepared from TgN1 and WT littermates at postnatal day 1 (P1). Briefly, after dissecting out the pups' brains, meninges were removed from both hemispheres. Brain tissues were washed once with pre-cooled dissecting media (DM; $1 \times$ HBSS, $1 \%$ penicillin-streptomycin, $10 \mathrm{mM}$ HEPES, $0.6 \%$ glucose solution). The brains were chopped and tissue pieces were transferred into a $60-\mathrm{mm}$ dish with a total volume of $4.5 \mathrm{~mL}$ DM plus $0.5 \mathrm{~mL}$ pre-warmed $2.5 \%$ Trypsin (Thermo Fisher Scientific), incubated at $37{ }^{\circ} \mathrm{C}$ for 15 min under horizontal agitation.

After enzymatic digestion, $100 \mu \mathrm{L}$ per dish of sterile $1 \mathrm{mg} /$ $\mathrm{mL}$ DNase I was added into dishes and gently swirled. The enzymatic activity was then quenched after 1 min with $5 \mathrm{~mL}$ of glial growth medium (GGM; DMEM + 0.6\% glucose solution, $1 \%$ penicillin-streptomycin, $10 \% \mathrm{FBS}$ ); the solution was gently pipetted up and down 2-3 times (on-dish trituration), transferred into a new $15-\mathrm{mL}$ falcon tube, and centrifuged for $5 \mathrm{~min}$ at $1000 \mathrm{rpm}$.

The pellet was resuspended in 5-mL neuronal maintenance medium (NMM; $1 \%$ Glutamax with a final concentration of $2 \mathrm{mM}, 2 \%$ B27 serum supplement, $1 \%$ penicillin-streptomycin, in 50-mL neurobasal medium), and cells were dissociated by 15 times pipetting up and down. After filtration through a $70 \mu \mathrm{m}$ cell strainer, cells were seeded onto PLL-coated dishes (poly-L-lysine hydrobromide, Sigma-Aldrich). The media was changed after 4-h incubation at $37^{\circ} \mathrm{C}$ and $5 \% \mathrm{CO}_{2}$. The next day, cells were treated with $10 \mu \mathrm{M}$ of the mitotic inhibitor fluorodeoxyuridine (FUdR, Sigma-Aldrich) overnight in order to eliminate non-neuronal cells. On day 5 post-dissection, cells and conditioned media were either harvested for analysis of protein expression or neurons were treated overnight with $5 \mu \mathrm{M}$ of proteasomal inhibitor (MG132) or left untreated in OptiMEM followed by harvesting.

\section{Co-culturing Primary Neurons on an Astrocyte Feeder Layer}

For morphological assessment, hippocampal neurons were co-cultured with hippocampal astrocytes following a previously published protocol [78]. Astrocytes were prepared 3 weeks before the day of neuronal dissection. For preparation of the astrocytes, hippocampi of four WT pups were pooled and chopped. After the first centrifugation step, brain tissues were triturated in GGM (described above). Astrocytes were seeded in T75 flasks and maintained up to 8 weeks in culture. One day before dissection of neurons, 80,000 astrocytes were seeded per well on 12-well plates with NMM. The next day, 60,000 neurons were plated on 18 -mm glass coverslips precoated with PLL. After $4 \mathrm{~h}$, coverslips were inverted face down over the feeder layer with wax dots in between (as spacers between dish and coverslip to separate the two cell types). Every 3 days, half of the media was exchanged.

\section{$A \beta$ Preparation and Treatment of Primary Neurons}

Treatment with synthetic $A \beta_{42}$ peptides (GenicBio Synthetic Peptide) has been described earlier [79]. Briefly, $\mathrm{A} \beta_{42}$ was dissolved in DMSO to the final concentration of a $2 \mathrm{mM}$ stock solution and aliquots were stored at $-80{ }^{\circ} \mathrm{C}$ and thawed immediately before use. On day 15 post-dissection, primary neurons on coverslips (see above) were separated from the astrocyte feeder culture and treated with a final concentration of $5 \mu \mathrm{M}$ monomeric $\mathrm{A} \beta_{42}$ for $12 \mathrm{~h}$ at $37^{\circ} \mathrm{C}$ in the cell culture incubator.

\section{Immunofluorescence Analysis of Hippocampal Primary Neurons and N2a Cells}

Media supernatant was aspirated from neurons plated on 18mm coverslips, and cells were washed with PBS, fixed with PFA solution (4\% PFA, 4\% sucrose in PBS), and then incubated for $10 \mathrm{~min}$ at room temperature (RT) on a shaker. After three washes with PBS, permeabilization with $0.25 \%$ Triton $\mathrm{X}-100$ (in PBS) was performed for $10 \mathrm{~min}$ at RT. Following three additional washes with PBS, blocking (with $1 \%$ BSA + $0.25 \%$ Triton X100) was done for $1 \mathrm{~h}$. Coverslips were incubated with primary antibodies against synaptophysin and MAP2 overnight at $4{ }^{\circ} \mathrm{C}$ while gently shaking. Next day, coverslips were washed three times with PBS and incubated with a fluorescent secondary antibody for $1 \mathrm{~h}$ at $\mathrm{RT}$ in the dark. All antibodies are listed in Suppl. Table 1A.

For quantification of dendritic spine density, primary neurons were obtained from two newborn mice per genotype. At least three images (i.e., three neurons) per mouse were taken by confocal laser scanning microscopy (TCS SP 5 , Leica). The gain settings were kept constant for all images acquired from the same experiment. Thereafter, TIFF images with merged channels were analyzed to measure synaptic punctae for 
selected regions of interest ( 3 to 5 dendritic segments per neuron) using SynPAnal software with a semi-automated puncta detection feature following a published protocol [80]. Puncta density values were used for the quantifications.

To study localization of transgenic N1, PrP-depleted (PrPKO) N2a cells (see below) grown on coverslips were assessed $48 \mathrm{~h}$ after transfection (see below). Cells were washed with PBS, fixed for 15 min at RT with 4\% PFA (in PBS), and again washed with PBS. Cells were blocked and permeabilized for $1 \mathrm{~h}$ in $10 \% \mathrm{FBS} / 0.1 \%$ glycine $/ 0.1 \%$ saponin and incubated with primary antibodies in $1 \% \mathrm{FBS} / 0.1 \%$ glycine $/ 0.1 \%$ saponin for $1 \mathrm{~h}$ at RT. Following three washes with PBS, incubation with secondary antibodies (in $1 \% \mathrm{FBS} / 0.1 \%$ glycine $/ 0.1 \%$ saponin) was for $30 \mathrm{~min}$. Additional washes with PBS were followed by mounting onto object slides using DAPI Fluoromount-G (Southern Biotech). Analysis was performed at a Leica TCS SP5 confocal microscope.

\section{N2a Cell Culture, CRISPR-Cas9 Genome Engineering, Transfections, and Treatments}

To generate a PrP knockout in murine neuroblastoma cells (N2a; ATCC $®$ CCL-131 ${ }^{\mathrm{TM}}$ ), we used the CRISPR-Cas9 system described by Zhang et al. [81]. Targeting sequences were designed using the Web-based tool CRISPR Design (http:// crispr.mit.edu/). The following target sequences directed to exon3 of the murine Prnp gene were used: sgRNA1_mPrP, ATTTTGCAGATCAGTCATCA; sgRNA3_mPrP, TCCTGATCGTGGGATGAGGG. The DNA sequences were synthesized (Sigma-Aldrich) and separately introduced into the plasmid vector pSpCas9(BB)-2A-Puro V2.0 (PX459; gift from Feng Zhang; Addgene plasmid \# 62988). The N2a cell line was maintained at $37^{\circ} \mathrm{C}$ under an atmosphere of $5 \%$ $\mathrm{CO}_{2}$ in Dulbecco's modified Eagle's medium (DMEM) + GlutaMAX $^{\mathrm{TM}}$ (Life Technologies) with 10\% ( $\left.v / v\right)$ fetal calf serum (FCS; Sigma-Aldrich) and $100 \mathrm{U} / \mathrm{mL}$ penicillin, $100 \mu \mathrm{g} / \mathrm{mL}$ streptomycin. All cells were free of mycoplasma. Cells were transfected with the recombinant plasmids using Lipofectamine 2000 (Life Technologies). Twenty-four hours post-transfection, cells were selected with $3 \mu \mathrm{g} / \mathrm{mL}$ puromycin for 3 days. Single-cell clones were then cultured with normal culture medium, followed by screening for genetic modifications in Prnp by PCR amplification and direct sequencing (GATC-Biotech) with the following primers: mPrP for, ACCTTCAGCCTAAATACTGG; mPrP rev, AGCAACTGGTCTACTGTACAT. The absence of protein was confirmed by immunoblotting.

To express PrP, N1, or N1 fusion proteins, cells were transfected with the respective constructs using Lipofectamine 2000 following the manufacturer's instructions. The antibody treatment of WT N2a cells was performed by adding $4 \mu \mathrm{g}$ of either POM1 or 6D11 to $1 \mathrm{~mL}$ media supernatant (fresh OptiMEM) for $18 \mathrm{~h}$.

\section{Biochemical Assessment of Cells, Conditioned Media, and Mouse Brains}

N2a cells or primary neurons were washed with cold PBS and lysed using RIPA buffer (with Complete EDTA-free protease (PI) and phosphatase (PhosStop) inhibitor cocktails (Roche)), incubated on ice for $15 \mathrm{~min}$ prior to centrifugation at $12,000 \mathrm{~g}$ for $10 \mathrm{~min}$ at $4{ }^{\circ} \mathrm{C}$. For SDS-PAGE, cell lysates were mixed with Laemmli buffer plus 5\% $\beta$-mercaptoethanol and denatured for 5 min at $95^{\circ} \mathrm{C}$.

For the analysis of the media supernatants (of N2a cells or primary neurons), experiments were carried out with freshly exchanged serum-free media (OptiMEM) incubated overnight. Supernatants were precipitated with trichloroacetic acid (TCA). For this, supernatants were collected and immediately incubated on ice with dissolved $10 \times$ concentrated protease inhibitor cocktail, cleared from dead cells and debris by consecutive mild centrifugations at $500 \mathrm{~g}$ and $5000 \mathrm{~g}$ for $5 \mathrm{~min}$ each. A total of $1 / 100$ volume of $2 \%$ sodium deoxycholate (NaDOC) was then added to each sample. After 30-min incubation on ice, samples were mixed with $1 / 10$ volume of $100 \%$ TCA and again incubated for $30 \mathrm{~min}$ on ice. After centrifugation at $15,000 \mathrm{~g}$ for $15 \mathrm{~min}$ at $4{ }^{\circ} \mathrm{C}$, the supernatant was aspirated and then air-dried for $5 \mathrm{~min}$. The pellet was completely resuspended in $100 \mu \mathrm{L}$ of $1 \times$ Laemmli buffer (incl. $5 \% \beta$-ME) and boiled for $5 \mathrm{~min}$ at $95^{\circ} \mathrm{C}$.

Fresh or frozen brain tissue from $\operatorname{TgN} 1$ or WT littermates was used to prepare $10 \%(w / v)$ homogenates in RIPA buffer (50 mM Tris-HCl pH 8, $150 \mathrm{mM} \mathrm{NaCl}, 1 \% \mathrm{NP}-40,0.5 \% \mathrm{Na}-$ Deoxycholate, $0.1 \%$ SDS) freshly supplemented with PI and PhosStop (except for the samples used for PK digestion) on ice. Samples were homogenized $30 \times$ using a Dounce homogenizer and incubated on ice for $15 \mathrm{~min}$, shortly vortexed and incubated for another $15 \mathrm{~min}$ prior to centrifugation at $12,000 \mathrm{~g}$ at $4{ }^{\circ} \mathrm{C}$ for $10 \mathrm{~min}$. Total protein content was assessed by Bradford assay (BioRad). Supernatants were either further processed for SDS-PAGE or stored at $-80^{\circ} \mathrm{C}$.

For assessment of $\mathrm{PrP}^{\mathrm{Sc}}$ levels in prion-infected mouse brains, $20 \%$ homogenates $(w / v)$ of frontal brain were prepared in RIPA buffer without protease inhibitors. Again, samples were smashed $30 \times$ on ice using a Dounce homogenizer and subsequently spun down at $2000 \mathrm{~g}$ for $2 \mathrm{~min}$. The resulting supernatant was collected and $2 \mu \mathrm{L}$ was digested with $20 \mu \mathrm{g} / \mathrm{mL}$ PK (Roche) in a total volume of $22-\mu \mathrm{L}$ RIPA buffer for $1 \mathrm{~h}$ at $37^{\circ} \mathrm{C}$ under mild agitation. Digestion was stopped by adding $6 \mu \mathrm{L}$ of $4 \times$ Laemmli buffer (incl. $5 \% \beta-\mathrm{ME}$ ) and boiled for $5 \mathrm{~min}$ at $95{ }^{\circ} \mathrm{C}$. Subsequent SDS-PAGE and Western blot analysis was performed as described above.

For SDS-PAGE, denatured samples were loaded on either precast Nu-PAGE 4-12\% Bis-Tris protein gels (Thermo Fisher Scientific) or Any kD ${ }^{\mathrm{TM}}$ Mini-PROTEAN® TGX ${ }^{\mathrm{TM}}$ Precast Protein Gels (BioRad). After electrophoretic separation, proteins were transferred to nitrocellulose membranes 
(BioRad) by wet-blotting and membranes were subsequently blocked for 30 min with $1 \times$ RotiBlock (Carl Roth) in TBS-T and incubated overnight with the respective primary antibody (Suppl. Table 1) diluted in either $5 \%$ BSA or $1 \times$ RotiBlock in TBS-T at $4{ }^{\circ} \mathrm{C}$ on a shaking platform.

Nitrocellulose membranes were subsequently washed with TBS-T and incubated for $1 \mathrm{~h}$ at RT with either HRP-conjugated secondary antibodies or in the dark with secondary antibody conjugates IRDye® ${ }^{\circledR}$ 680RD and 800CW (Li-Cor) and subsequently washed $5 \times$ with TBS-T. For classical chemilumiscence detection, after incubation with Pierce ECL Pico or Super Signal West Femto substrate (Thermo Fisher Scientific), signal was detected with a ChemiDoc imaging station (BioRad). The fluorescence signals were detected using an Odyssey CLX system (Li-Cor). Densitometric quantification was done using the Image studio lite version 5.2.

\section{Real-Time Quantitative Polymerase Chain Reaction}

Mouse brain tissues from forebrain or cerebellum (about $100 \mathrm{mg}$ ) were collected and homogenized with $1 \mathrm{~mL}$ TRIzol and incubated for $5 \mathrm{~min}$ at RT to permit the complete dissociation, and then centrifuged at $12,000 \mathrm{~g}$ for $10 \mathrm{~min}$ at $4{ }^{\circ} \mathrm{C}$. The upper phase was collected after centrifugation and $200 \mu \mathrm{L}$ chloroform were added to each sample and vigorously shaken by hand for $15 \mathrm{~s}$ and incubated at RT for 2-3 min. The upper aqueous phase was collected after centrifugation of the mixture at $12,000 \mathrm{~g}$ for $15 \mathrm{~min}$ at $4{ }^{\circ} \mathrm{C}$ and, subsequently, $500 \mu \mathrm{L}$ of $100 \%$ isopropanol were added to the collected aqueous phase and incubated for $10 \mathrm{~min}$ at RT. After another centrifugation step, the RNA pellet was washed twice with $1 \mathrm{~mL}$ of $75 \%$ ethanol, vortexed and centrifuged at $7500 \mathrm{~g}$ for $5 \mathrm{~min}$ at $4{ }^{\circ} \mathrm{C}$. After air-drying for 5-10 min, the pellet was dissolved in DEPC water and heated at $55{ }^{\circ} \mathrm{C}$ for $10 \mathrm{~min}$. Purity and concentration of RNA were assessed by NanoDrop ${ }^{\mathrm{TM}}$ measurement (Thermo Scientific). The cDNA was synthesized using reverse transcriptase with a two-step method using RevertAid H Minus First Strand cDNA Synthesis Kit (Thermo Scientific). Every reagent was added according to the manufacturer's instructions. Three replicates were set for each group. The ribosomal protein L13 (RPL13) was used as the reference gene, and the relative expression level of PrP was calculated by the $2^{-\Delta \Delta \mathrm{Ct}}$ method [82]. Primers are listed in Suppl. Table 1B.

\section{Histological Assessment}

Morphological analysis was performed as described previously [83]. After collecting the brains, they were fixed in $4 \%$ paraformaldehyde (PFA) overnight. In the case of prion- or mock-inoculated animals, samples were initially inactivated for $1 \mathrm{~h}$ in $98-100 \%$ formic acid before being exported from the respective biosafety facility. After several washes with water, samples were again incubated overnight with $4 \%$ PFA at $4{ }^{\circ} \mathrm{C}$. Afterwards, samples were embedded in low melting point paraffin according to the standard laboratory procedures. Sections with $4 \mu \mathrm{m}$ thickness were prepared and stained either with hematoxylin and eosin (HE) or following standard immunohistochemistry procedures using the Ventana Benchmark XT machine (Ventana, Tucson, AZ). Briefly, for antigen retrieval, deparaffinated sections were boiled for 30 $60 \mathrm{~min}$ in $10 \mathrm{mM}$ citrate buffer $(\mathrm{pH} 6.0)$. All primary antibodies (see Suppl. Table 1A) were prepared in $5 \%$ goat serum (Dianova, Hamburg, Germany), 45\% Tris buffered saline with $0.1 \%$ Triton X-100 (TBST) pH 7.6, in antibody diluent solution (Zytomed, Berlin, Germany). Detection was performed with anti-rabbit or anti-goat histofine Simple Stain MAX PO Universal immunoperoxidase polymer or Mouse Stain Kit (for detection of mouse antibodies on mouse sections). All secondary antibody polymers were purchased from Nichirei Biosciences (Tokyo, Japan). For detection of antibodies, Ultra View Universal DAB Detection Kit or Ultra View Universal Alkaline Phosphatase Red Detection Kit from Ventana were used according to standard settings of the machine. Experimental groups were stained all at the same time to provide identical conditions. For $\mathrm{PrP}^{\mathrm{Sc}}$ staining, pre-mounted tissue sections with 4- $\mu \mathrm{m}$ thickness were first treated with 98$100 \%$ formic acid for $5 \mathrm{~min}$ and further processing was performed with the above-mentioned automated staining machine. Briefly, sections were pretreated with $1.1 \mathrm{mM}$ sodium citrate buffer (2.1 mM Tris-HCl, $1.3 \mathrm{mM}$ EDTA, pH 7.8) at $95{ }^{\circ} \mathrm{C}$ for $30 \mathrm{~min}$, digested with low concentration of PK for $16 \mathrm{~min}$, incubated first in Superblock for $10 \mathrm{~min}$ and then with the PrP-specific antibody SAF84, followed by secondary antibody treatment and detection.

\section{Statistical Analysis}

Statistical analysis of Western blot results, morphological quantifications of dendritic spines, and qRT-PCR results between experimental groups was performed using Student's $t$ test and assessment of significance for incubation times after prion inoculation was performed using log-rank (Mantel-Cox) test for two-group comparisons with consideration of statistical significance at $p$ values $<0.05(*),<0.01(* *)$, and $<0.001$ $(* * *)$.

\section{Results}

\section{Generation and Characterization of TgN1 Mice: Transgenic Overexpression of N1 Does Not Result in Obvious Phenotypic Alterations}

The released, soluble N1 fragment of $\operatorname{PrP}^{\mathrm{C}}$ has been linked to neuroprotective functions in neurodegenerative conditions; yet, the protease responsible for its endogenous production 
remains obscure. Therefore, to directly assess the role of $\mathrm{N} 1$ in prion diseases, we generated transgenic mice ( $\mathrm{TgN} 1)$ stably overexpressing N1 under the control of the prion protein promotor (using the half genomic construct [77]) on a wildtype (C57Bl/6) background (as expression of $\mathrm{PrP}^{\mathrm{C}}$ is a prerequisite for prion disease [84]). These mice neither presented any obvious behavioral alterations nor differences in size (Fig. 2a) or body weight ( $n=3$; SEM; Fig. $2 b)$ when compared to wild-type (WT) littermate controls. Overexpression of the transgene was confirmed on the genetic level by copy number analysis $(\Delta \Delta \mathrm{Ct}=-3.913$, corresponding to a fold change of 15; data not shown) and on the mRNA level for cerebellum (TgN1: $3.41 \pm 0.58$; WT set to $1.00 \pm 0.15 ; n=3$; SEM; Fig. 2c) and forebrain (TgN1: $2.37 \pm 0.48$; WT set to $1.00 \pm 0.24 ; n=3$; SEM; Fig. 2d). Note that primers used for RT-qPCR bind to regions coding for the N-terminal part of $\operatorname{PrP}^{\mathrm{C}}$ and therefore do not per se discriminate the $\mathrm{N} 1$ transgene from endogenous Prnp. Most importantly, western blot (WB) analysis of freshly prepared forebrain homogenates clearly proved overexpression of N1 (in 8-week-old mice: $3.8 \pm$ 0.14 for TgN1; WT set to $1.00 \pm 0.12 ; n=4$; SEM; Fig. 2e) that was even more pronounced in aged mice (at 43 weeks: $5.2 \pm 0.44$ for TgN1; WT set to $1.00 \pm 0.14 ; n=4$; SEM; Fig. 2f), whereas levels of full-length $\operatorname{PrP}^{\mathrm{C}}$ and an N-terminal PrP fragment of $\sim 20 \mathrm{kDa}$ (possibly corresponding to N3 resulting from the recently described $\gamma$-cleavage [85]) were not altered between genotypes. However, in TgN1 mice, our biochemical analysis also revealed the presence of a conspicuous double band at $\sim 11 \mathrm{kDa}$, i.e., the expected molecular weight of $\mathrm{N} 1$ (indicated by a question mark in Fig. 2e, f). To better clarify the nature of those N-terminal fragments, we performed a differential analysis of mouse brain homogenates by comparing bands detected with two $\mathrm{N}$-terminally binding antibodies with the ones obtained with two C-terminally directed antibodies (Fig. 1; Suppl. Fig. 1a) and size comparison with recombinant N1 (Suppl. Fig. 1b). These analyses provided further support that the $\sim 20 \mathrm{kDa}$ band is obviously N3. Importantly, they let us to conclude that the band running slightly higher than bona fide N1 most likely represents N1 with an uncleaved Nterminal signal peptide (N1-SP), which will be further discussed below.

Since it is conceivable that transgenic N1 expression could influence the endogenous $\alpha$-cleavage of $\operatorname{PrP}^{\mathrm{C}}$, we compared levels of the $\mathrm{C} 1$ fragment in brain homogenates of $\mathrm{TgN} 1$ and WT mice (Suppl. Fig. 1c). As no significant differences were found, no feedback effect of transgenic N1 on the $\alpha$-cleavage rate seems to be present. a

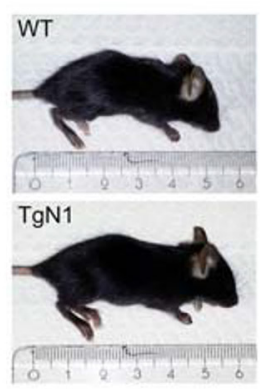

b

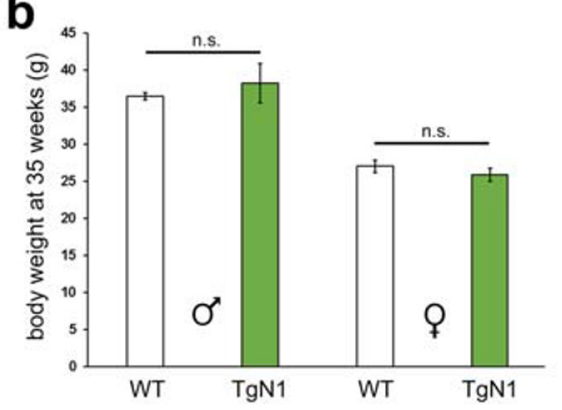

C

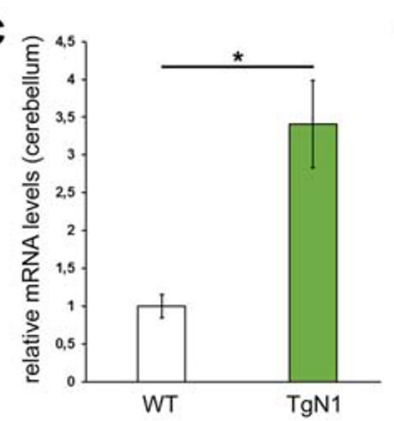

d

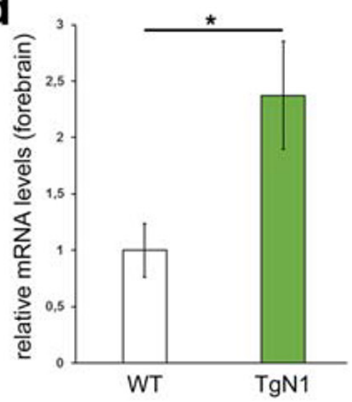

e

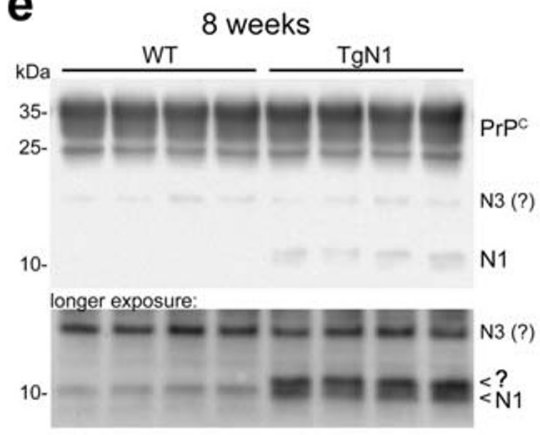

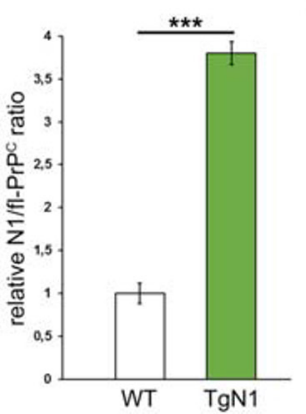

Fig. 2 Characterization of TgN1 mice. Body size (a) and body weight measurements $(\mathbf{b} ; n=3)$ reveal no significant differences between $\mathrm{TgN} 1$ and the age-matched WT littermates. c, d RT-qPCR analysis in mouse brain homogenates showing higher mRNA expression levels in $\mathrm{TgN} 1$ compared to WT controls in cerebellum (c; $n=3 ; p=0.031)$ and forebrain (d; $n=3 ; p=0.028)$. (e, f) Western blot analyses of forebrain samples of $\mathbf{e}$ 8 -week-old $(n=4 ; p=0.00001)$ and $\mathbf{f} 43$-week-old mice $(n=4 ; p=$ 0.0047 ) (measured as ratio of N1 fragment to corresponding fl-PrP; both $\mathbf{f}$
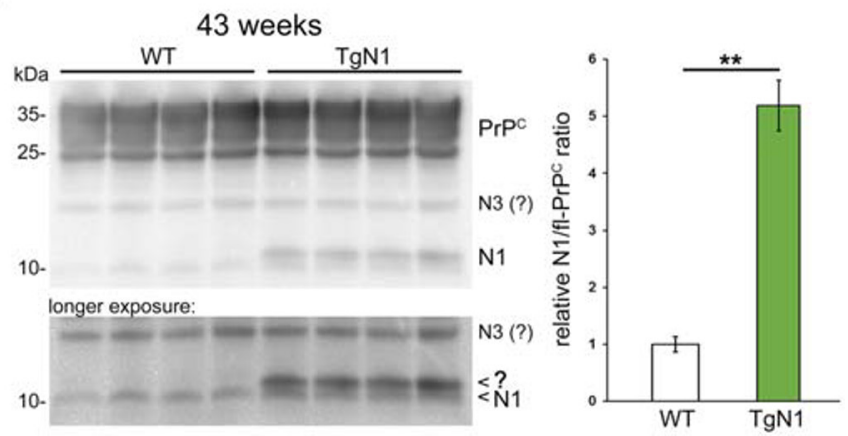

detected by POM2 antibody) reveal a double band (arrowheads; upper band indicated by a "?") and a strong increase in the levels of N1 fragments in TgN1 mice (note that in the case of TgN1 the double band was measured as "N1"). Taken together, these data demonstrate successful generation of transgenic mice overexpressing N1. In addition, a fragment of $\sim 20 \mathrm{kDa}$, possibly representing the endogenous N3 fragment resulting from the $\gamma$-cleavage of $\operatorname{PrP}^{\mathrm{C}}$, is readily detected in brain homogenates 
Next, we investigated whether key candidate signaling pathways associated with $\mathrm{PrP}^{\mathrm{C}}$ or N1 were influenced by transgenic overexpression of N1 in 43-week-old mice. Upon biochemical assessment, no alterations in the ratio of phosphorylated and total levels of protein kinase B (Akt), eukaryotic initiation factor 2 (eIF2 $\alpha$ ), or MAP kinases Erk1/2 and p38 could be detected in forebrain homogenates (Suppl. Fig. 2).

Lastly, (immuno)histochemical analyses did not reveal any neuropathological alterations in 8-week-old TgN1 mice when compared to WT littermates with regard to overall brain morphology, content and distribution of mature neurons, cellular proliferation and microglial activation in cortical (Fig. 3a), and cerebellar areas (Fig. 3b) as well as in hippocampus (Fig. 3c). For older mice, refer to Suppl. Fig. 3.

\section{Increased PrPS ${ }^{\text {Sc }}$ Levels and p38 MAP Kinase Activation but Unchanged Disease Course in Prion-Infected TgN1 Mice}

After confirming expression of the transgene, we intracerebrally inoculated $\mathrm{TgN} 1$ mice and WT littermates with mouse-adapted RML. Unexpectedly, mice of both genotypes presented with an equal disease course reaching terminal disease at similar time-points (mean: $\mathrm{TgN} 1+$ RML: $160 \pm 7$ days; $n=10$; WT + RML: $159 \pm 9$ days; $n=9$; $\mathrm{SD}$ ), whereas mice (of both genotypes) inoculated with a non-pathogenic control homogenate (CD1) were sacrificed without any clinical signs at day 240 (Fig. 4a). We next performed WB analyses of brain homogenates obtained from terminally prion-diseased and CD1-inoculated control mice of both genotypes (Fig. 4b). Again, a double band for N1 is apparent in TgN1 samples with the upper one (likely representing N1-SP) running slightly higher than endogenous N1 (in WT). Prion conversion in RML-infected mice of both genotypes was confirmed by (i) increased levels of total PrP species (i.e., $\operatorname{PrP}^{\mathrm{C}}$ plus $\operatorname{PrP}^{\mathrm{Sc}}$ ), (ii) a shifted glycopattern, and (iii) appearance of SDS-stable oligomeric PrP conformers when compared to CD1-inoculated samples (Fig. 4b, c). A surprising reduction in levels of endogenous N1 was detected in prion-diseased WT mice. Although this would require further analyses, it may indicate recruitment of $\mathrm{N} 1$ into insoluble $\operatorname{PrP}^{\mathrm{Sc}}$ aggregates or reduced $\alpha$-cleavage efficiency in prion disease. Of note, we found slightly but significantly higher levels of total PrP in infected TgN1 versus WT mice (TgN1 + RML: $1.63 \pm 0.05$; compared to WT + RML: $1.34 \pm 0.04$; with non-infected WT(+CD1) set to $1.00 \pm 0.07 ; n=3$; SEM; Fig. $4 \mathrm{c}$ ). This increase was likely due to higher $\operatorname{PrP}^{\mathrm{Sc}}$ levels $(\mathrm{TgN} 1+\mathrm{RML}$ : $1.32 \pm 0.05 ; \mathrm{WT}+\mathrm{RML}$ set to $1.00 \pm 0.06 ; n=4 ; \mathrm{SEM}$ ) as assessed upon digestion of brain homogenates with proteinase $\mathrm{K}$ (PK) (Fig. 4d). We next investigated signaling pathways associated with $\mathrm{PrP}^{\mathrm{C}}$ and prion diseases. While no relevant differences were found in the phosphorylation state of the MAP kinase Erk1/2, prion infection resulted in slightly elevated phosphorylation of Akt and significantly increased activation of the Src kinase Fyn (Fig. 4e). However, no differences were observed between genotypes. In contrast, we found a significant increase in the activating phosphorylation of the MAP kinase $\mathrm{p} 38$ in infected $\mathrm{TgN} 1$ mice compared to infected controls (TgN1 + RML: $2.49 \pm 0.26$; WT + RML set to $1.00 \pm 0.07 ; n=4$; SEM; Fig. 4 f). This difference between genotypes was not observed in non-infected mice (Suppl. Fig. 2).

Histological analysis of neuropathological hallmarks, such as astrogliosis, microglia activation, and spongiosis, confirmed fully established prion disease in RML-infected compared to CD1-inoculated mice, yet did not reveal any overt differences between genotypes (Suppl. Fig. 3).

In summary, transgenic $\mathrm{N} 1$ overexpression did not result in protection against prion disease. By contrast, $\mathrm{PrP}^{\mathrm{Sc}}$ levels and p38 MAPK signaling were even increased in terminal TgN1 mice yet did not alter the clinical course and incubation time.

\section{Transgenically Expressed N1 Does Not Protect Against A $\beta$-Mediated Synaptotoxicity}

$\mathrm{N} 1$ was shown to bind to $A \beta$ in the extracellular space and to protect neurons from $A \beta$-associated toxicity [38]. Synaptotoxicity, which precedes neuronal loss in neurodegenerative conditions, can be assessed by quantification of dendritic spines [30]. To study the effects of transgenic N1 overexpression, primary neurons were obtained from $\mathrm{TgN} 1$ mice and WT littermates and maintained in co-culture with an astrocyte feeder layer. Microscopic analysis (Fig. 5) revealed no differences in overall morphology and relative density of dendritic spines for TgN1 (TgN1: $0.999 \pm 0.052$; WT set to 1.00 \pm 0.092 ; SEM) between neurons of both genotypes when treated with solvent only (+mock; Fig. 5a, c). Thus, transgenic overexpression of $\mathrm{N} 1$ does not cause alterations in neuronal morphology or dendritic spine density. Upon $12 \mathrm{~h}$ of treatment with synthetic $\mathrm{A} \beta_{42}$ (Fig. 5b,c), dendritic spine density was significantly reduced compared to mock-treated neurons (with "WT + A $\beta$ ": $0.764 \pm 0.047$ and "TgN1 + A $\beta$ ": $0.665 \pm 0.055$; SEM). However, there were no significant differences between $A \beta$-treated neurons from both genotypes. This indicates that, as observed above for prion diseases (Fig. 4), transgenic overexpression of $\mathrm{N} 1$ does not confer protection against exogenously administered proteopathic entities.

\section{Impaired ER Translocation Results in Retention of Transgenic N1 Fragments (with Likely Uncleaved ER-Targeting Signal Peptide) in the Cytosol}

To explain this lack of protection in spite of confirmed overexpression of the assumedly beneficial N1 fragment in the 
Fig. 3 Lack of overt morphological alterations in young TgN1 mice. a, b Neither $\mathrm{H} \& \mathrm{E}$ staining nor

immunohistochemical detection of microglia (Iba1) and neurons $(\mathrm{NeuN})$ revealed any alterations between eight-week-old WT and TgN1 mice in cortical $(\mathrm{Cx} ; \mathbf{a})$ or cerebellar brain regions $(\mathrm{Cb} ; \mathbf{b})$. $\mathbf{c}$ Likewise, neuronal density (assessed by neuronal marker $\mathrm{NeuN}$ ) and amounts of proliferating cells (assessed by the marker Mib/Ki67) were similar between both genotypes in the hippocampus $(\mathrm{Hc})$. Scale bars represent $100 \mu \mathrm{m}$
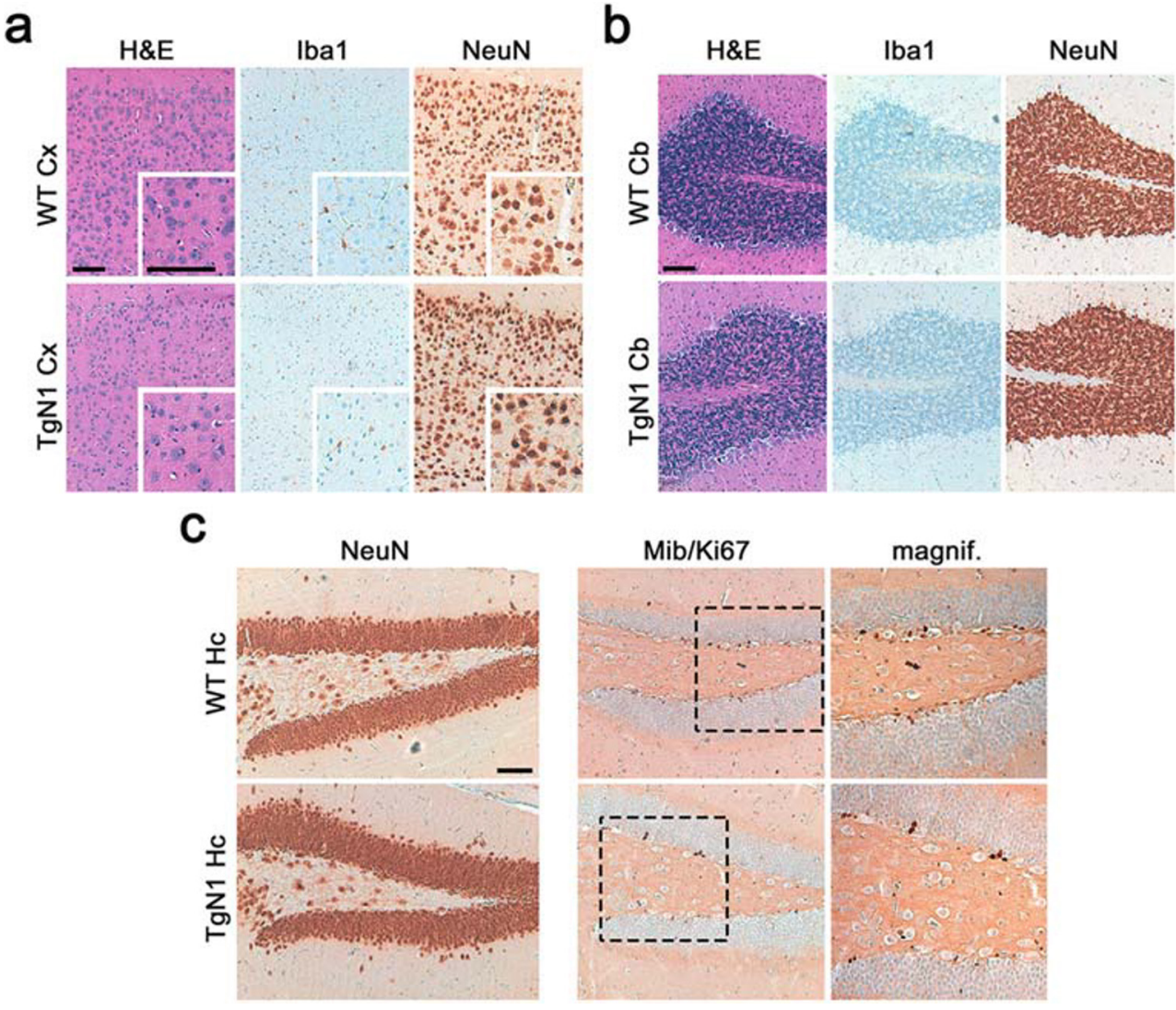

Mib/Ki67

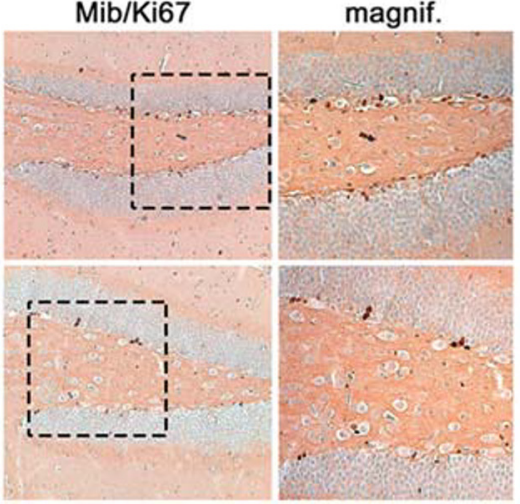

brains of $\mathrm{TgN} 1$ mice, we performed further analyses at the cellular level.

We first studied the secretion of N1 by primary neurons into the media supernatant by WB analysis. While overexpression of the transgene was confirmed in corresponding neuronal lysates (Fig. 6a), no such increase of N1 was observed in the conditioned media of $\mathrm{TgN} 1$ neurons (TgN1: $0.75 \pm 0.17$; WT set to $1.00 \pm 0.19 ; n=3$; SEM; Fig. 6a, b), indicating that transgenic N1 was not (or only poorly) secreted but rather retained in the cells. This is in strong agreement with cell culture studies revealing impaired translocation of IDDs into the ER [6, 86, 87]. Accordingly, transgenic N1 (with unprocessed N-terminal signal peptide (SP)) would be retained in the cytosol. To study this, we inhibited proteasomal degradation and performed WB analysis (Fig. 6c). As expected, this proteasomal inhibition (confirmed by elevated levels of $\beta$-catenin) increased $\mathrm{N} 1$ fragments in the cytosol of $\mathrm{TgN} 1$ neurons, supporting the concept that transgenic N1 is not (efficiently) imported into the ER but rather stays in the cytosol. This probably also explains the presence of the double band (lower band: N1 ( $10 \mathrm{kDa})$; upper band: N1 with uncleaved signal peptide (N1-SP $\sim 12 \mathrm{kDa})$ ) observed in brain samples of TgN1 mice throughout this study (Figs. $2 \mathrm{e}$, f and $4 \mathrm{~b}$ ) and reveals for the first time that ER translocation and secretion of IDDs is also impaired in vivo.
To further study the cellular localization of ectopically expressed N1, we transiently transfected N2a cells devoid of endogenous PrP (PrP-KO N2a cells). In stark contrast to WTPrP, which was mainly found at the plasma membrane, cells expressing N1 alone revealed a strong cytosolic staining (Fig. 7). In conclusion, biochemical data showing (i) a TgN1-restricted double band with the upper band running higher than bona fide N1, (ii) accumulation of that fragment upon proteasomal inhibition, and (iii) impaired secretion of transgenic N1, together with (iv) a morphological analysis revealing cytosolic localization strongly suggest that transgenic N1 is retained inside cells with an uncleaved SP.

\section{Aspects to Be Considered When Devising Improved Transgenic Mouse Models for N1-Based Therapeutic Approaches}

To better understand the intricate nature of different $\mathrm{N} 1$ forms found in biochemical analyses [48], we finally performed additional experiments in murine neuroblastoma (N2a) cells. We and others have repeatedly experienced difficulties in the reliable detection of endogenous, proteolytically generated N1, which may result from its low biostability, fast degradation upon release [54], and general "stickiness" (e.g., towards plastic surfaces; recent own observation) among others. In WB analyses of conditioned media as well as in cell lysates and 

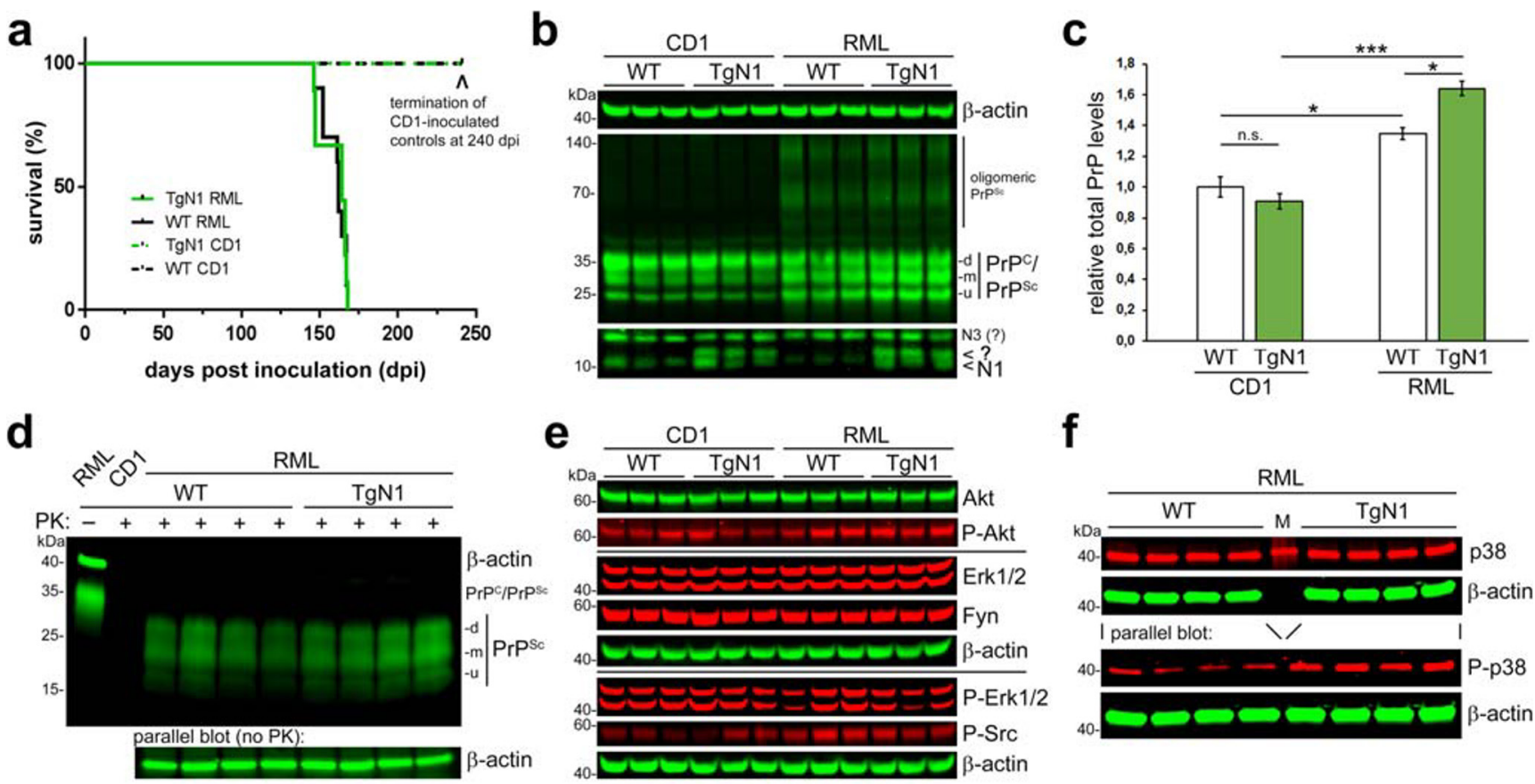

f
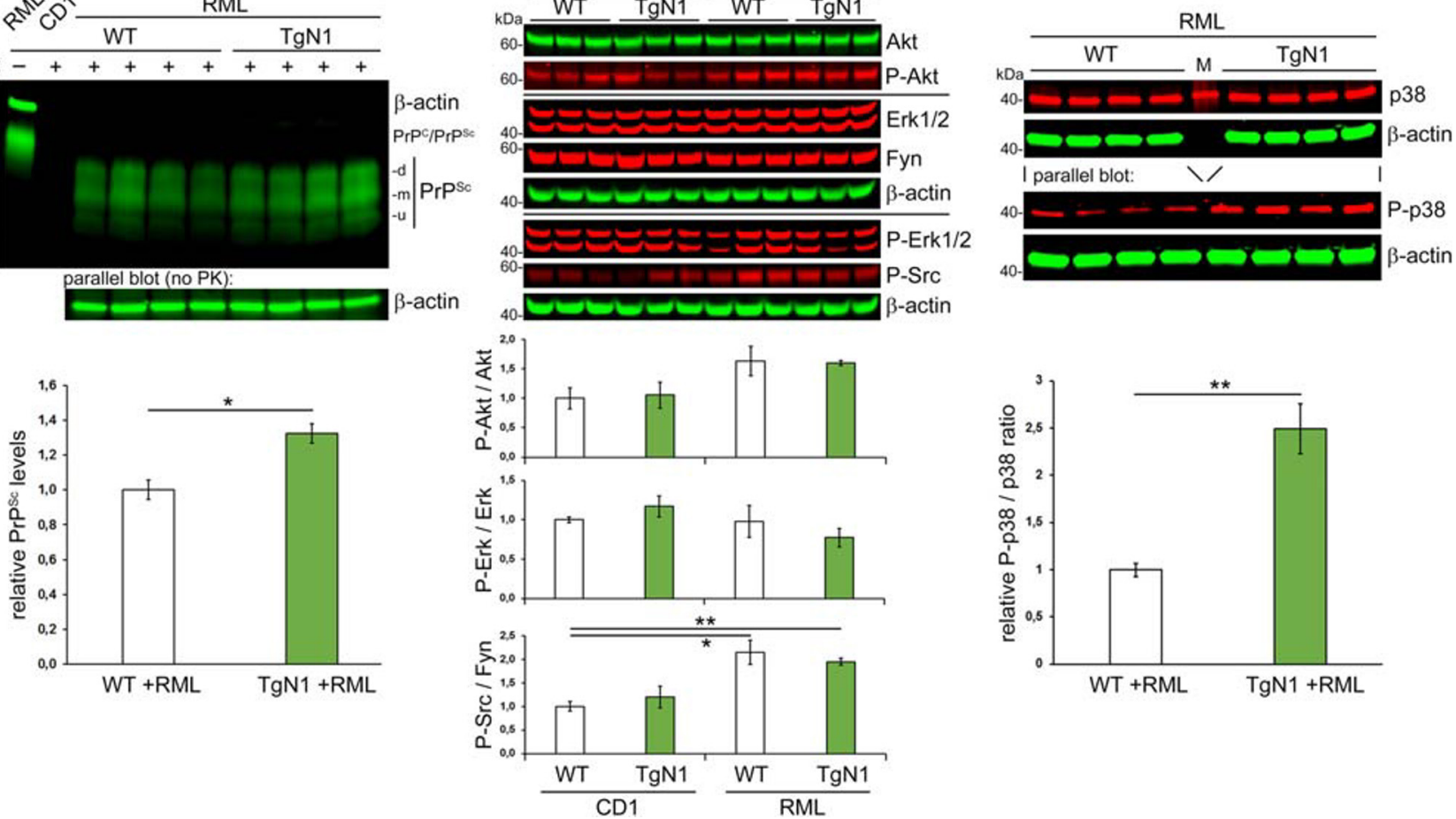

Fig. 4 Intracerebral inoculation of $\mathrm{TgN} 1$ and control mice with prions. a Kaplan-Meier survival curve of mice upon intracerebral inoculation with mouse-adapted RML prions showing similar incubation times to terminal prion disease for $\operatorname{TgN} 1(n=10)$ and WT littermates $(n=9)$, whereas the mock-inoculated control groups of each genotype (inoculated with CD1 brain homogenate) did not show any clinical signs until sacrification at 240 days post-inoculation $(n=4)$. b Western blot analysis of infected and non-infected mouse brain homogenates showing an altered glycopattern and presence of oligomeric $\operatorname{PrP}^{\mathrm{Sc}}$ forms in prion-infected samples and increased total $\operatorname{PrP}$ levels (i.e., $\operatorname{PrP}^{\mathrm{C}}$ and $\operatorname{PrP}^{\mathrm{Sc}}$ ) in terminally diseased TgN1 mice (quantification in $\mathbf{c} ; p=0.0167 ; n=3$ ). d Western blot of PK-digested brain samples of terminally diseased mice of both genotypes (quantification was done by normalizing the $\operatorname{PrP}^{\mathrm{Sc}}$ signals (POM1

brain homogenates that had undergone freezing and thawing (e.g., Fig. 6a, c), but not in freshly prepared brain homogenates or cell lysates (e.g., Figs. 2e, f or 4b), "N1" presented with several bands of slightly lower molecular weight than bona fide N1 [59, 88], indicative of a proteolytic trimming event. To further assess this, we analyzed endogenously produced N1 in conditioned media of N2a wild-type cells. While fragmentation of $\mathrm{N} 1$ was again observed in control-treated antibody) against actin on the parallel blot with non-digested samples) $(n=4 ; p=0.0167)$. Controls (on the left) include a non-digested RMLinfected brain homogenate and a CD1-inoculated PK-digested brain sample. The shift in molecular weight and disappearance of the actin signal confirm successful enzymatic digestion. e, f Western blot analyses of candidate signaling pathways associated with prion disease showing $\mathbf{e}$ no differences in the phosphorylation state of Erk $1 / 2$, slightly elevated $\mathrm{P}$-Akt and significantly increased activation of the $\mathrm{P}-\mathrm{Src}$ in prion-infected mice (WT + CD1 vs. WT + RML: $p=0.027 ; \mathrm{WT}+\mathrm{CD} 1$ vs. TgN1 + RML: $p=0.003 ; n=3$ ) and $\mathbf{f}$ a significant increase in the activating phosphorylation of $\mathrm{p} 38$ in infected $\mathrm{TgN} 1$ samples compared to infected controls $(p=0.0032 ; n=4)$

overnight cultures, treatment of cells with an antibody against the epitope ranging from amino acid 93 to 109 (corresponding to the C-terminal end of N1) completely blocked this trimming (Suppl. Fig. 4a). This finding demonstrates that N1, once released (either by physiological $\alpha$-cleavage or by disruption of cells and tissue), is stepwise truncated from its $\mathrm{C}$ terminus assumingly through unspecific cleavage by extracellular proteases. This may explain N1's low biostability and, 


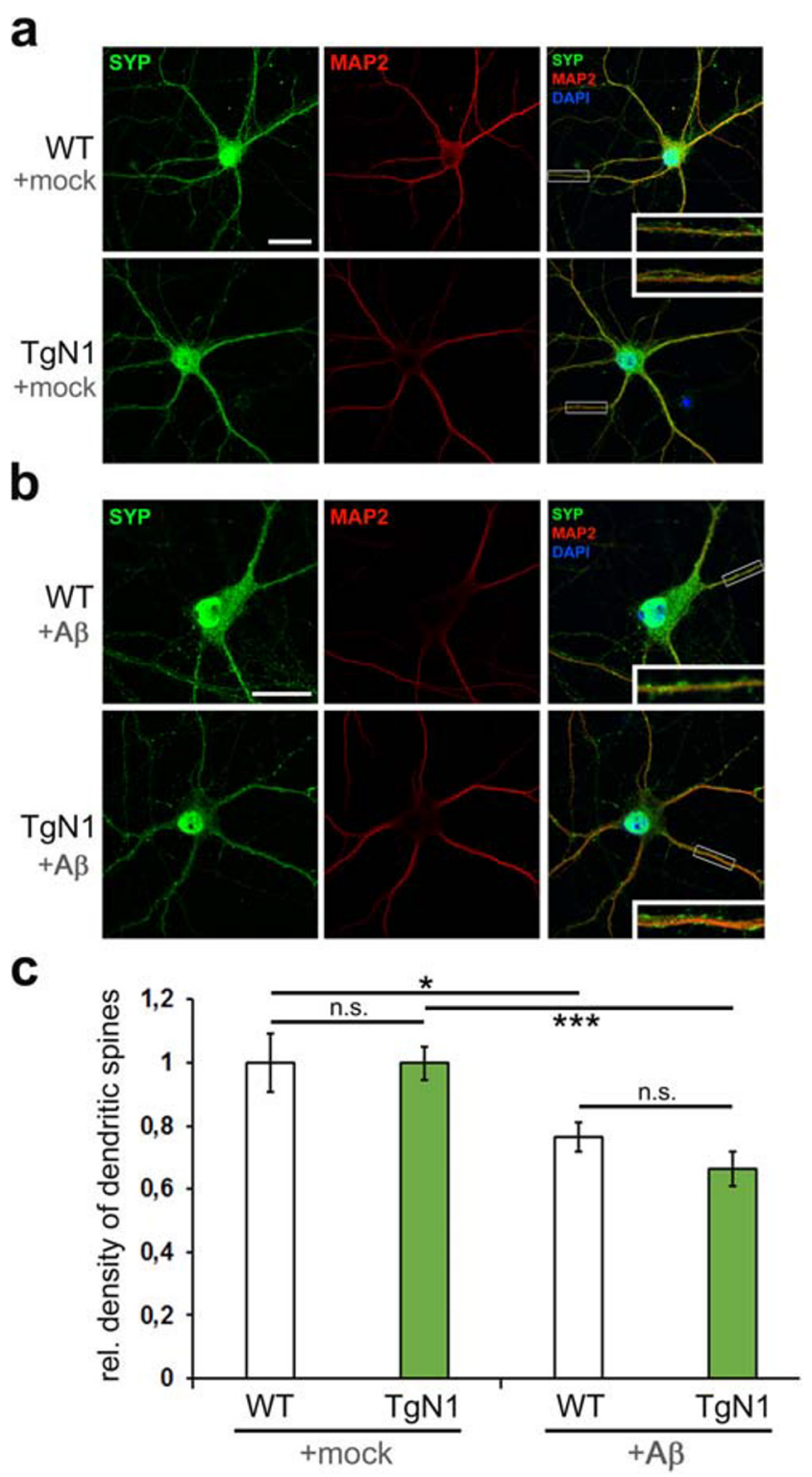

Fig. 5 Morphological assessment and $A \beta_{42}$ treatment of primary neurons derived from $\operatorname{TgN} 1$ and control mice. a Representative images from primary neurons grown in a co-culture system conditioned with an astrocyte feeder layer for 2 weeks, indicating no difference in overall morphology and dendritic spines density (green dots) between TgN1 and WT neurons (quantification in $\mathbf{c}$ ). $\mathrm{SYP}=$ synaptophysin (green); $\mathrm{MAP} 2=\mathrm{mi}-$ crotubule-associated protein 2 (red). b, c Treatment of neurons with synthetic $A \beta_{42}$ resulted in a decrease in dendritic spine density compared to mock-treated controls (a, c); yet, no differences were found between treated neurons of both genotypes $(\mathbf{b}, \mathbf{c})$. Scale bar is $25 \mu \mathrm{m}$

given that the trimming affects one of N1's described $A \beta$ binding sites (aa 95-110 [36]), indicates the need of a stabilizing C-terminal modification when considering treatment options based on exogenous administration of N1 derivates. Moreover, this trimming impairs binding of certain antibodies with epitopes in this region, such as the commercially available 6D11 and 3F4 antibodies. Lastly, it may be considered to generate fragments mimicking bona fide $\mathrm{N} 2$ resulting from the $\operatorname{PrP}^{\mathrm{C}} \beta$-cleavage.

It has been described that, for ER translocation of a given peptide sequence to be successful, structural elements, such as $\alpha$-helical domains, have to be present in the nascent chain [87, 89]. In the case of $\operatorname{PrP}^{\mathrm{C}}$, these criteria are fulfilled by its structured C-terminal half (Fig. 1) [86]; yet, transgenically expressed N1 is lacking these elements and is therefore retained in the cytosol (as shown here in mice and earlier in vitro [6]). To overcome this problem and to allow for efficient $\mathrm{N} 1$ secretion and increased biostability (by protection from the C-terminal trimming mentioned above; Suppl. Fig. 4a), we expressed N1-fusion proteins harboring either the $\mathrm{Fc}$ region of an $\mathrm{IgG}(\mathrm{N} 1 \mathrm{Fc})$ or a nanobody $(\mathrm{N} 1 \mathrm{Nb}) \mathrm{C}$ terminal of N1 in PrP-depleted N2a cells. As expected [38], in contrast to $\mathrm{N} 1$ alone (of which only low amounts were detected in media thus reflecting its impaired translocation and secretion), both $\mathrm{N} 1 \mathrm{Fc}$ and $\mathrm{N} 1 \mathrm{Nb}$ were efficiently secreted and could be readily detected in conditioned media (Suppl. Fig. 4b). Of note, in addition to the respective full-length fusion proteins, we also detected a lower band likely corresponding to bona fide N1. This indicates that $\alpha$-cleavage (or an $\alpha$-cleavage-like proteolytic event) still occurs, even if (not necessarily membrane-anchored) structure-lending protein tags replace the $\mathrm{C}$-terminal half of $\mathrm{PrP}^{\mathrm{C}}$. This further highlights the extreme tolerance of this cleavage event described earlier [72].

\section{Discussion}

An increasing body of evidence indicating protective effects of PrP-N1 in neurodegenerative conditions let us to generate transgenic mice overexpressing this fragment and enabling detailed studies in animals. However, likely due to the lack of $\alpha$-helical elements in the nascent chain, transgenically expressed N1 was not or only inefficiently translocated into the ER and, hence, not or poorly secreted into the extracellular space but rather retained (seemingly with the uncleaved $\mathrm{N}$ terminal signal peptide (N1-SP)) in the cytosol. As such, our study is the first mouse model to illustrate the requirements of structured domains in secretory proteins for efficient ER translocation, as shown previously in cultured cells $[6,86,87,89]$. Accordingly, though the N-terminal ER-targeting SP is necessary $[90,91]$, it is not sufficient to bestow efficient translocation for all proteins determined to be secreted. In the case of largely unstructured proteins, additional structural elements (i.e., $\alpha$-helical domains) are required at one point in the growing peptide chain in order to be translocated.

Consequently, C-terminal addition of an IgG Fc part (as already shown earlier [38]) or a nanobody rescued N1 secretion in our experiment. Although transgenic N1 was not or only poorly secreted but aberrantly located in the cytosol, our 
a

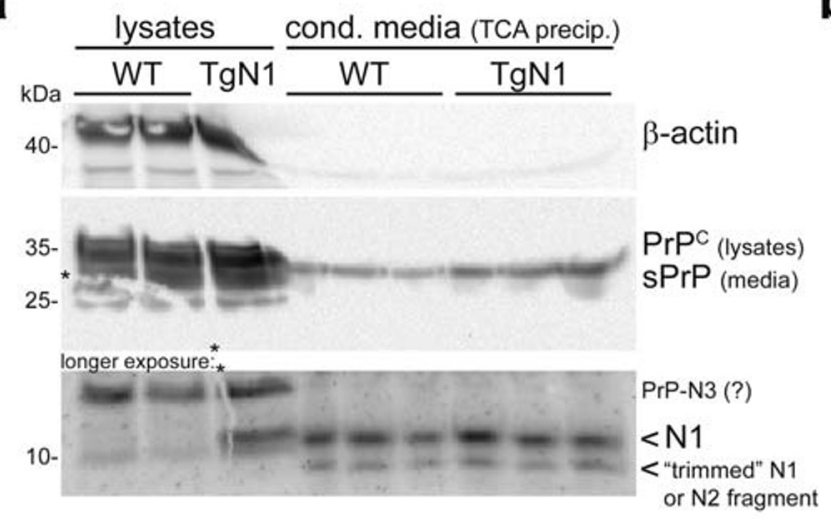

C

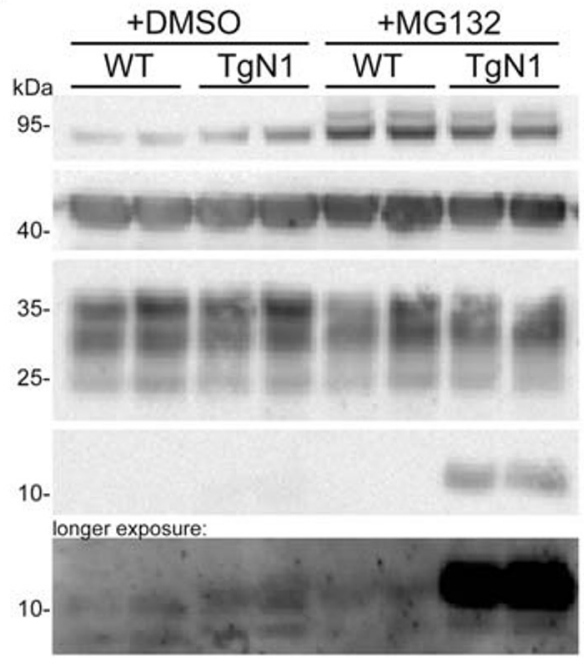

Fig. 6 Transgenically expressed N1 is not or only poorly secreted and rather retained with uncleaved SP in the cytosol. a Lysates and conditioned media of primary neurons (in mono-culture) from WT and $\mathrm{TgN} 1$ mice were biochemically analyzed for $\mathrm{N} 1$ and $\mathrm{PrP}^{\mathrm{C}}$. While overexpression of $\mathrm{N} 1$ is confirmed in lysates of $\mathrm{TgN} 1$ neurons (note the double band), no increase (instead rather a tendency towards decrease (b)) in N1 is found in the respective media supernatants. Note that a band lower than N1 is detected in media which may represent "trimmed" N1 (see Suppl. Fig. 4a) or endogenous N2 resulting from the $\beta$-cleavage of $\operatorname{PrP}^{\mathrm{C}}$. b Densitometric quantification of $\mathbf{a} ; n=3$; levels of $\mathrm{N} 1$ signals were referred to levels of shed $\operatorname{PrP}$ found in media (a band possibly

study provides relevant insight into different aspects of prion pathophysiology and reveals aspects to be considered for future studies on N1-based treatment approaches. Along our analyses, we also found indications that the N3 fragment resulting from the $\gamma$-cleavage of $\operatorname{PrP}^{\mathrm{C}}$ [85] can be readily detected in normal mouse brain and may thus bear physiological relevance.

\section{No Protection of Cytosolic N1 Against Proteopathic Seeds}

Presence of aberrant subcellular forms, including cytosolic PrP (cytPrP), has been described decades ago [92-96]. b

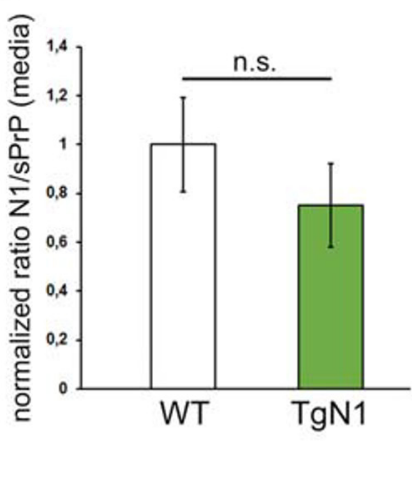

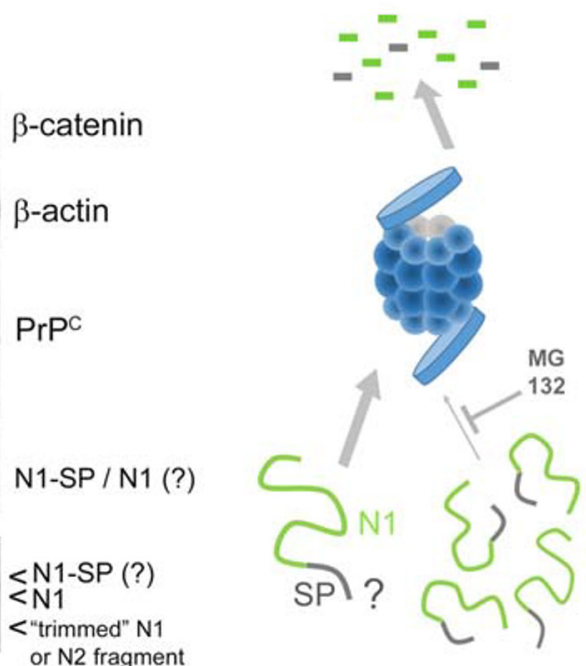

$<\mathrm{N} 1$

$<$ "trimmed" N1 or N2 fragment corresponding to N3 was detected in lysates but not in supernatants). c Primary neurons treated with an inhibitor of the proteasome (+MG132) or diluent only (+DMSO; as control) followed by Western blot analysis of lysates for levels of $\mathrm{N} 1$ fragments, $\operatorname{PrP}^{\mathrm{C}}, \beta$-catenin, and $\beta$-actin (note that the low biostability of $\mathrm{N} 1$ may lead to fast degradation explaining the occasional need for longer exposure. As mentioned above, a weak band running lower than $10 \mathrm{kDa}$ might reflect N2 or "trimmed" N1). Block of the proteasome results in a strong increase of an N1 fragment-most likely-N1-SP (here appearing as just one strong band) in the cytosol (as indicated in the scheme on the right)

CytPrP may result from pathogenic mutations, retrotranslocation from the ER in various conditions of cellular stress, or from inefficient ER translocation [97-99] and is found under physiological conditions in neurons of different brain regions [100]. Aggregation-prone cytPrP is constitutively cleared by the proteasome; yet, impairment of this degradation results in cytoplasmic accumulation [97, 98, 101]. Fittingly, upon proteasomal inhibition, we also observed drastic accumulation of N1 with uncleaved SP in TgN1 primary neurons.

To date, there is still some controversy regarding putative pathophysiological roles played by cytPrP. While some studies found cytPrP accumulation to cause neurotoxicity and cell 
Fig. 7 Cytosolic retention of ectopically expressed N1. PrPKO N2a cells were transfected with plasmids coding for either WT-PrP or N1 alone. Nontransfected cells served as negative controls. Immunfluorescent stainings on fixed and permeabilized cells revealed a predominant membrane-staining for WTPrP with both PrP-directed antibodies (POM2 and POM1, red), whereas cells transfected with N1 showed a strong cytosolic staining pattern (note that POM1 does not detect $\mathrm{N} 1$; specificity control). GM130 $($ green $)=$ Golgi marker. Scale bars represent $20 \mu \mathrm{m}$ (upper panel) or $10 \mu \mathrm{m}$ (lower two pictures)

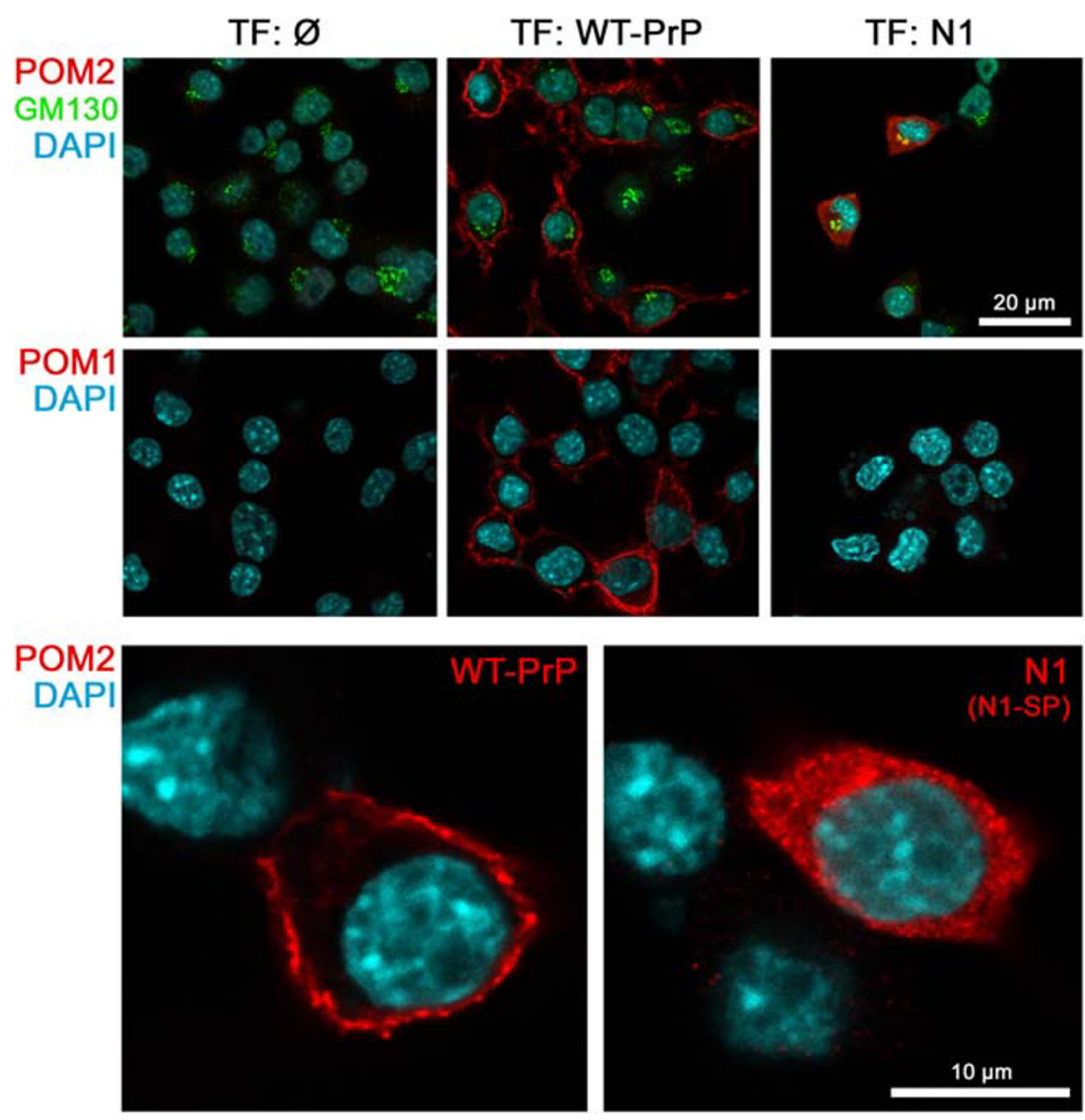

death per se [102-104], others found no adverse effects and rather indicated cell-protective activities [105-107]. Likewise, the contribution of cytPrP to the misfolding and neurotoxicity in prion diseases still remains enigmatic. Though cytPrP expressed in Drosophila was not toxic per se, it contributed to the detrimental effects when exposed to prions [108]. Several other studies have also pointed towards a harmful role of cytPrP in prion diseases [102, 109, 110]. At least two-not mutually exclusive - paradigms of prion-associated toxicity are currently being put forward by supportive experimental data: a model of "external toxicity" emphasizes binding of extracellular prions (and other proteopathic seeds, such as $\mathrm{A} \beta$ oligomers) to surface $\operatorname{PrP}^{\mathrm{C}}$ inducing neurotoxic signaling cascades and/or membrane perturbations [3, 31, 36, 38, 111-113], whereas another concept describes detrimental effects of intracellular (including cytoplasmic) prions abrogating essential homeostatic and degradative processes of the cell including the ubiquitin-proteasome system (UPS) [102, 114-119]. While our study did not directly address the importance of cytosolic PrP species in prion diseases, lack of effects in our transgenic mice with high N1 (or better: N1-SP) levels in the cytoplasm (as demonstrated in N1-transfected cells) at least indicates that $\mathrm{N} 1$ does not confer protection against cytPrP-mediated toxicity or cytosolic prions.

In contrast to any protective effects, the only difference found between our transgenic and control mice upon prion infection was a moderate increase in forebrain $\mathrm{PrP}^{\mathrm{Sc}}$ levels in TgN1. Given that the proteasome is involved in $\operatorname{PrP}^{\mathrm{Sc}}$ degradation $[102,114,120-122]$, it is conceivable that the massive overproduction of cytosolic N1 to some extent reduced the efficiency of the proteasome to degrade $\mathrm{PrP}^{\mathrm{Sc}}$. And since activation of the MAP kinase p38 has been specifically linked to the toxic signaling underlying prion diseases [113, 123, 124], it seems likely that the increase in p38 phosphorylation in our $\mathrm{TgN} 1$ mice at terminal prion disease is a consequence of the elevated $\operatorname{PrP}^{\mathrm{Sc}}$ levels.

In $\mathrm{AD}$, cellular uptake of $\mathrm{A} \beta$ occurs and intraneuronal accumulation of $A \beta$ has been linked to $A \beta$-induced neurotoxicity [125]. In our experiments, cytoplasmic N1 did neither confer protection against prions nor against $A \beta$ induced neurotoxicity. Since exogenously administered N1 reliably blocks $\mathrm{A} \beta$-induced neurotoxicity [38, 64-71], our data rather support a model where $A \beta$ induced neurotoxicity is mainly executed by events occurring at the plasma membrane of neurons. 


\section{Cytoplasmic N1-SP Does Not Behave Like a Cell-Penetrating Peptide}

The shortest N-terminal PrP fragment shown to behave as a bona fide prion is caused by a stop mutation at aa145 and found in Gerstmann-Sträussler-Scheinker syndrome [126]. However, conversion and the infectious character of this PrP mutant depends on residues 112-139 which are lacking in our $\mathrm{N} 1$ construct. In fact, the disordered N1 alone is unlikely to undergo prion-like misfolding or mediate toxic effects. Yet there have been reports showing that cytPrP forms with uncleaved SP or artificially expressed PrP fragments composed of the SP and the first few residues of the charged cluster (PrP1-28 or PrP1-30) behave as CPPs [33-35]. Such PrP versions were shown to form intracellular aggregates, to destabilize the cytoskeleton and to exert membrane perturbations $[35,104,127]$. Fitting to the latter, when attached to the outer leaflet of the plasma membrane, the N-terminal part of $\operatorname{PrP}^{\mathrm{C}}$ alone was shown to induce ionic currents, which might be associated with integration into membranes [29]. In strong contrast to these harmful effects, other studies have linked the PrP-derived CPPs with anti-prion properties as they have found reduced $\operatorname{PrP}^{\mathrm{Sc}}$ levels in infected cells treated with these CPPs $[128,129]$.

Our transgenic mice showed cytosolic retention of - what we consider to be-N1-SP, which by containing the abovementioned sequences would potentially qualify as a CPP. However, we did not find any evidence for detrimental effects such as an overtly disturbed cytoskeleton (as judged by the morphology of cerebral neurons in brain sections or primary neurons (e.g., MAP2)), dendritic spine loss or altered signaling that would recapitulate earlier findings made for PrP1-30 [35]. This indicates that cytosolic N1-SP is unable to penetrate membranes and to exert deleterious effects. As discussed above, we also did not find any protective anti-prion action of cytosolic N1-SP described earlier or exogenously administered PrP-CPPs [128, 129]. Fittingly, while N1 was shown to enter the cytosol when applied to cell culture supernatants (thus confirming its capacity to penetrate membranes), protective effects of $\mathrm{N} 1$ did not depend on this internalization but rather on its extracellular presence [61]. The latter study also showed involvement of the Akt pathway in the neuroprotection mediated by extracellular N1; yet, cytoplasmic N1 in our transgenic mice did not cause alterations in this cascade.

\section{Conclusions and Outlook}

Our study provides the first in vivo proof of the impaired ER translocation of IDDs, in this case resulting in the aberrant retention of N1-SP in the cytoplasm. As such, this TgN1 animal model may become a valuable resource to study mechanisms and consequences of a hindered ER import despite presence of an ER-targeting SP and an active translocon.
Moreover, this model may provide in vivo insight into the interaction between the $\operatorname{PrP}^{\mathrm{C}} \mathrm{N}$-terminus and RNAs and its role in phase separation processes in the cytoplasm [130,131].

Although cytosolic N1-SP contains the relevant CPP motif described by others, it neither causes overtly deleterious perturbations of intracellular membranes, the cytoskeleton or signaling pathways, nor does it exert any anti-prion effect previously ascribed to shorter PrP-derived CPPs. This supports the view that protective effects of $\mathrm{N} 1$ are strongly dependent on its presence in the extracellular space, i.e., its physiological localization endogenously ensured by the constitutive $\alpha$ cleavage of $\operatorname{PrP}^{\mathrm{C}}$. Since the identity of the responsible protease(s) is unclear, transgenic overexpression of N1 remains a valid strategy to study its protective effects against neurodegeneration in vivo. However, findings highlighted here, such as the need for structured $\mathrm{C}$-terminal tags to allow for efficient translocation/secretion and to avoid degradative proteolytic trimming, or the extreme tolerance of the $\alpha$-PrPase(s) to Cterminal modifications, have to be considered. As a consequence, we have recently generated transgenic mice overexpressing $\mathrm{N} 1 \mathrm{Fc}$ that will likely provide further insight into N1associated protection against neurodegenerative diseases and beyond.

Acknowledgments The authors would like to thank Dr. Irm HermansBorgmeyer (Transgenic Mouse Facility, ZMNH/UKE Hamburg), the UKE Microscopy Imaging Facility (umif), and Kristin Hartmann (Mouse Pathology Facility, UKE Hamburg) for their valuable technical support. We would like to thank Dr. Feng Zhang (Broad Institute) for providing the PX459 V2.0 plasmid.

Funding Information Open Access funding provided by Projekt DEAL. This work was supported by the Creutzfeldt-Jakob Disease (CJD) Foundation, Inc. (to HCA), the Werner-Otto-Stiftung (to BP and HCA), and the Deutsche Forschungsgemeinschaft (DFG; GRK1459 to BM and MG; CRC877 project A12 to MG; TA167/11 to JT).

\section{Compliance with Ethical Standards}

Ethics Statement Animal experiments were carried out in accordance with the recommendations in the Guide for the Care and Use of Laboratory Animals of the German Animal Welfare Act on protection of animals. Procedures were done in accordance with the guidelines of the animal facility of the University Medical Center Hamburg-Eppendorf and approved by the Committee on Ethics of the Freie und Hansestadt Hamburg (permit number 84/13).

Open Access This article is licensed under a Creative Commons Attribution 4.0 International License, which permits use, sharing, adaptation, distribution and reproduction in any medium or format, as long as you give appropriate credit to the original author(s) and the source, provide a link to the Creative Commons licence, and indicate if changes were made. The images or other third party material in this article are included in the article's Creative Commons licence, unless indicated otherwise in a credit line to the material. If material is not included in the article's Creative Commons licence and your intended use is not permitted by statutory regulation or exceeds the permitted use, you will need to obtain permission directly from the copyright holder. To view a copy of this licence, visit http://creativecommons.org/licenses/by/4.0/. 


\section{References}

1. Riek R, Hornemann S, Wider G, Glockshuber R, Wüthrich $\mathrm{K}$ (1997) NMR characterization of the full-length recombinant murine prion protein, $\mathrm{mPrP}(23-231)$. FEBS Lett 413(2):282-288

2. Zahn R, Liu A, Luhrs T, Riek R, von Schroetter C, Lopez Garcia F, Billeter M, Calzolai L et al (2000) NMR solution structure of the human prion protein. Proc Natl Acad Sci U S A 97(1):145-150

3. Sonati T, Reimann RR, Falsig J, Baral PK, O'Connor T, Hornemann S, Yaganoglu S, Li B et al (2013) The toxicity of antiprion antibodies is mediated by the flexible tail of the prion protein. Nature 501:102-106

4. Riek R, Hornemann S, Wider G, Billeter M, Glockshuber R, Wüthrich K (1996) Nmr structure of the mouse prion protein domain Prp(121-231). Nature 382(6587):180-182

5. Donne DG, Viles JH, Groth D, Mehlhorn I, James TL, Cohen FE, Prusiner SB, Wright PE et al (1997) Structure of the recombinant full-length hamster prion protein $\operatorname{PrP}(29-231)$ : the $\mathrm{N}$ terminus is highly flexible. Proc Natl Acad Sci U S A 94(25):13452-13457

6. Gonsberg A, Jung S, Ulbrich S, Origi A, Ziska A, Baier M, Koch HG, Zimmermann R et al (2017) The Sec61/SecY complex is inherently deficient in translocating intrinsically disordered proteins. J Biol Chem 292:21383-21396

7. Borgia A, Borgia MB, Bugge K, Kissling VM, Heidarsson PO, Fernandes CB, Sottini A, Soranno A et al (2018) Extreme disorder in an ultrahigh-affinity protein complex. Nature 555(7694):61-66

8. Beland M, Roucou X (2012) The prion protein unstructured Nterminal region is a broad-spectrum molecular sensor with diverse and contrasting potential functions. J Neurochem 120(6):853-868

9. Kostylev MA, Tuttle MD, Lee S, Klein LE, Takahashi H, Cox TO, Gunther EC, Zilm KW et al (2018) Liquid and hydrogel phases of $\operatorname{PrP}(\mathrm{C})$ linked to conformation shifts and triggered by Alzheimer's amyloid-beta oligomers. Mol Cell 72(3):426-443 e12

10. Taylor DR et al (2005) Assigning functions to distinct regions of the $\mathrm{N}$-terminus of the prion protein that are involved in its copperstimulated, clathrin-dependent endocytosis. J Cell Sci 118 (Pt 21): 5141-5153

11. Walter ED, Chattopadhyay M, Millhauser GL (2006) The affinity of copper binding to the prion protein octarepeat domain: evidence for negative cooperativity. Biochemistry 45(43):13083-13092

12. Watt NT, Taylor DR, Kerrigan TL, Griffiths HH, Rushworth JV, Whitehouse IJ, Hooper NM (2012) Prion protein facilitates uptake of zinc into neuronal cells. Nat Commun 3:1134

13. Ulbrich S, Janning P, Seidel R, Matschke J, Gonsberg A, Jung S, Glatzel M, Engelhard M et al (2018) Alterations in the brain interactome of the intrinsically disordered N-terminal domain of the cellular prion protein (PrPC) in Alzheimer's disease. PLoS One 13(5): 0197659

14. Shyng SL, Huber MT, Harris DA (1993) A prion protein cycles between the cell surface and an endocytic compartment in cultured neuroblastoma cells. J Biol Chem 268(21):15922-15928

15. Shyng SL, Moulder KL, Lesko A, Harris DA (1995) The Nterminal domain of a glycolipid-anchored prion protein is essential for its endocytosis via clathrin-coated pits. J Biol Chem 270(24): $14793-14800$

16. Walmsley AR, Zeng F, Hooper NM (2003) The N-terminal region of the prion protein ectodomain contains a lipid raft targeting determinant. J Biol Chem 278(39):37241-37248

17. Nunziante M, Gilch S, Schatzl HM (2003) Essential role of the prion protein $\mathrm{N}$ terminus in subcellular trafficking and half-life of cellular prion protein. J Biol Chem 278(6):3726-3734

18. Taylor DR, Hooper NM (2007) The low-density lipoprotein receptor-related protein 1 (LRP1) mediates the endocytosis of the cellular prion protein. Biochem J 402(1):17-23
19. Parkyn CJ, Vermeulen EGM, Mootoosamy RC, Sunyach C, Jacobsen C, Oxvig C, Moestrup S, Liu Q et al (2008) LRP1 controls biosynthetic and endocytic trafficking of neuronal prion protein. J Cell Sci 121(Pt 6):773-783

20. Flechsig E, Shmerling D, Hegyi I, Raeber AJ, Fischer M, Cozzio A, von Mering C, Aguzzi A et al (2000) Prion protein devoid of the octapeptide repeat region restores susceptibility to scrapie in PrP knockout mice. Neuron 27(2):399-408

21. Supattapone S, Muramoto T, Legname G, Mehlhorn I, Cohen FE, DeArmond SJ, Prusiner SB, Scott MR (2001) Identification of two prion protein regions that modify scrapie incubation time. $\mathrm{J}$ Virol 75(3):1408-1413

22. Mallucci G, Dickinson A, Linehan J, Klöhn PC, Brandner S, Collinge J (2003) Depleting neuronal PrP in prion infection prevents disease and reverses spongiosis. Science 302(5646):871874

23. Solforosi L, Bellon A, Schaller M, Cruite JT, Abalos GC, Williamson RA (2007) Toward molecular dissection of PrPCPrPSc interactions. J Biol Chem 282(10):7465-7471

24. Rambold AS, Müller V, Ron U, Ben-Tal N, Winklhofer KF, Tatzelt J (2008) Stress-protective signalling of prion protein is corrupted by scrapie prions. EMBO J 27(14):1974-1984

25. Turnbaugh JA, Unterberger U, Saa P, Massignan T, Fluharty BR, Bowman FP, Miller MB, Supattapone S et al (2012) The N-terminal, polybasic region of $\operatorname{PrP}(\mathrm{C})$ dictates the efficiency of prion propagation by binding to $\operatorname{PrP}(\mathrm{Sc})$. J Neurosci 32(26):8817-8830

26. Kocisko DA, Come JH, Priola SA, Chesebro B, Raymond GJ, Lansbury PT, Caughey B (1994) Cell-free formation of proteaseresistant prion protein. Nature 370(6489):471-474

27. Silveira JR, Raymond GJ, Hughson AG, Race RE, Sim VL, Hayes SF, Caughey B (2005) The most infectious prion protein particles. Nature 437(7056):257-261

28. Sigurdson CJ, Bartz JC, Glatzel M (2019) Cellular and molecular mechanisms of prion disease. Annu Rev Pathol 14:497-516

29. Wu B, McDonald AJ, Markham K, Rich CB, McHugh KP, Tatzelt J, Colby DW, Millhauser GL et al (2017) The N-terminus of the prion protein is a toxic effector regulated by the $\mathrm{C}$-terminus. Elife 6

30. Fang C, Imberdis T, Garza MC, Wille H, Harris DA (2016) A neuronal culture system to detect prion synaptotoxicity. PLoS Pathog 12(5):e1005623

31. Biasini E, Turnbaugh JA, Unterberger U, Harris DA (2012) Prion protein at the crossroads of physiology and disease. Trends Neurosci 35(2):92-103

32. Solomon IH, Biasini E, Harris DA (2012) Ion channels induced by the prion protein: mediators of neurotoxicity. Prion 6(1):40-45

33. Lundberg P, Magzoub M, Lindberg M, Hällbrink M, Jarvet J, Eriksson LEG, Langel Ü, Gräslund A (2002) Cell membrane translocation of the N-terminal (1-28) part of the prion protein. Biochem Biophys Res Commun 299(1):85-90

34. Magzoub M, Oglęcka K, Pramanik A, Göran Eriksson LE, Gräslund A (2005) Membrane perturbation effects of peptides derived from the $\mathrm{N}$-termini of unprocessed prion proteins. Biochim Biophys Acta 1716(2):126-136

35. Zajkowski T, Nieznanska H, Nieznanski K (2015) Stabilization of microtubular cytoskeleton protects neurons from toxicity of Nterminal fragment of cytosolic prion protein. Biochim Biophys Acta 1853(10 Pt A):2228-2239

36. Lauren $\mathrm{J}$ et al (2009) Cellular prion protein mediates impairment of synaptic plasticity by amyloid-beta oligomers. Nature 457(7233):1128-1132

37. Chen S, Yadav SP, Surewicz WK (2010) Interaction between human prion protein and amyloid-beta (Abeta) oligomers: role OF N-terminal residues. J Biol Chem 285(34):26377-26383

38. Resenberger UK, Harmeier A, Woerner AC, Goodman JL, Müller V, Krishnan R, Vabulas RM, Kretzschmar HA et al (2011) The 
cellular prion protein mediates neurotoxic signalling of beta-sheetrich conformers independent of prion replication. EMBO J 30(10): 2057-2070

39. Larson M, Sherman MA, Amar F, Nuvolone M, Schneider JA, Bennett DA, Aguzzi A, Lesne SE (2012) The complex PrPc-Fyn couples human Oligomeric Abeta with pathological tau changes in Alzheimer's disease. J Neurosci 32(47):16857-16871

40. Rushworth JV, Griffiths HH, Watt NT, Hooper NM (2013) Prion protein-mediated toxicity of amyloid-beta oligomers requires lipid rafts and the transmembrane LRP1. J Biol Chem 288(13):89358951

41. Dohler F, Sepulveda-Falla D, Krasemann S, Altmeppen H, Schlüter H, Hildebrand D, Zerr I, Matschke J et al (2014) High molecular mass assemblies of amyloid-beta oligomers bind prion protein in patients with Alzheimer's disease. Brain 137(Pt 3):873886

42. Haas LT, Salazar SV, Kostylev MA, Um JW, Kaufman AC, Strittmatter SM (2016) Metabotropic glutamate receptor 5 couples cellular prion protein to intracellular signalling in Alzheimer's disease. Brain 139(Pt 2):526-546

43. Ferreira DG, Temido-Ferreira M, Vicente Miranda H, Batalha VL, Coelho JE, Szegö ÉM, Marques-Morgado I, Vaz SH et al (2017) Alpha-synuclein interacts with PrPC to induce cognitive impairment through mGluR5 and NMDAR2B. Nat Neurosci 20(11): 1569-1579

44. Ondrejcak T, Klyubin I, Corbett GT, Fraser G, Hong W, Mably AJ, Gardener M, Hammersley J et al (2018) Cellular prion protein mediates the disruption of hippocampal synaptic plasticity by soluble tau in vivo. J Neurosci 38(50):10595-10606

45. Gomes LA, Hipp SA, Rijal Upadhaya A, Balakrishnan K, Ospitalieri S, Koper MJ, Largo-Barrientos P, Uytterhoeven V et al (2019) Abeta-induced acceleration of Alzheimer-related tau-pathology spreading and its association with prion protein. Acta Neuropathol 138:913-941

46. Harris DA, Huber MT, van Dijken P, Shyng SL, Chait BT, Wang $\mathrm{R}$ (1993) Processing of a cellular prion protein: identification of Nand C-terminal cleavage sites. Biochemistry 32(4):1009-1016

47. Chen SG, Teplow DB, Parchi P, Teller JK, Gambetti P, AutilioGambetti L (1995) Truncated forms of the human prion protein in normal brain and in prion diseases. J Biol Chem 270(32):1917319180

48. Mange A et al (2004) Alpha- and beta- cleavages of the aminoterminus of the cellular prion protein. Biol Cell 96(2):125-132

49. Walmsley AR, Watt NT, Taylor DR, Perera WSS, Hooper NM (2009) Alpha-cleavage of the prion protein occurs in a late compartment of the secretory pathway and is independent of lipid rafts. Mol Cell Neurosci 40(2):242-248

50. Shmerling D, Hegyi I, Fischer M, Blättler T, Brandner S, Götz J, Rülicke T, Flechsig E et al (1998) Expression of amino-terminally truncated PrP in the mouse leading to ataxia and specific cerebellar lesions. Cell 93(2):203-214

51. Baumann F, Tolnay M, Brabeck C, Pahnke J, Kloz U, Niemann HH, Heikenwalder M, Rülicke T et al (2007) Lethal recessive myelin toxicity of prion protein lacking its central domain. EMBO J 26(2):538-547

52. Li A, Barmada SJ, Roth KA, Harris DA (2007) N-terminally deleted forms of the prion protein activate both Bax-dependent and Bax-independent neurotoxic pathways. J Neurosci 27(4): 852-859

53. Solomon IH, Khatri N, Biasini E, Massignan T, Huettner JE, Harris DA (2011) An N-terminal polybasic domain and cell surface localization are required for mutant prion protein toxicity. J Biol Chem 286(16):14724-14736

54. Yusa S, Oliveira-Martins JB, Sugita-Konishi Y, Kikuchi Y (2012) Cellular prion protein: from physiology to pathology. Viruses 4(11):3109-3131
55. Biasini E, Unterberger U, Solomon IH, Massignan T, Senatore A, Bian H, Voigtlaender T, Bowman FP et al (2013) A mutant prion protein sensitizes neurons to glutamate-induced excitotoxicity. J Neurosci 33(6):2408-2418

56. Lewis V, Hill AF, Haigh CL, Klug GM, Masters CL, Lawson VA, Collins SJ (2009) Increased proportions of C1 truncated prion protein protect against cellular M1000 prion infection. J Neuropathol Exp Neurol 68(10):1125-1135

57. Westergard L, Turnbaugh JA, Harris DA (2011) A naturally occurring C-terminal fragment of the prion protein (PrP) delays disease and acts as a dominant-negative inhibitor of PrPSc formation. J Biol Chem 286(51):44234-44242

58. Campbell L, Gill AC, McGovern G, Jalland CMO, Hopkins J, Tranulis MA, Hunter N, Goldmann W (2013) The PrP(C) C1 fragment derived from the ovine A136R154R171PRNP allele is highly abundant in sheep brain and inhibits fibrillisation of fulllength $\operatorname{PrP}(\mathrm{C})$ protein in vitro. Biochim Biophys Acta 1832(6): 826-836

59. Beland $\mathrm{M}$ et al (2014) Abeta induces its own prion protein Nterminal fragment (PrPN1)-mediated neutralization in amorphous aggregates. Neurobiol Aging 35(7):1537-1548

60. Corda E, du X, Shim SY, Klein AN, Siltberg-Liberles J, Gilch S (2018) Interaction of peptide aptamers with prion protein central domain promotes alpha-cleavage of $\operatorname{Pr} P(C)$. Mol Neurobiol 55(10): 7758-7774

61. Guillot-Sestier MV, Sunyach C, Druon C, Scarzello S, Checler F (2009) The alpha-secretase-derived N-terminal product of cellular prion, N1, displays neuroprotective function in vitro and in vivo. J Biol Chem 284(51):35973-35986

62. Kuffer A et al (2016) The prion protein is an agonistic ligand of the G protein-coupled receptor Adgrg6. Nature 536(7617):464-468

63. Linsenmeier L et al (2017) Diverse functions of the prion protein does proteolytic processing hold the key? Biochim Biophys Acta 1864(11 Pt B):2128-2137

64. Calella AM, Farinelli M, Nuvolone M, Mirante O, Moos R, Falsig J, Mansuy IM, Aguzzi A (2010) Prion protein and Abeta-related synaptic toxicity impairment. EMBO Mol Med 2(8):306-314

65. Guillot-Sestier MV, Sunyach C, Ferreira ST, Marzolo MP, Bauer C, Thevenet A, Checler F (2012) Alpha-Secretase-derived fragment of cellular prion, N1, protects against monomeric and oligomeric amyloid beta (Abeta)-associated cell death. J Biol Chem 287(7):5021-5032

66. Nieznanski K, Choi JK, Chen S, Surewicz K, Surewicz WK (2012) Soluble prion protein inhibits amyloid-beta (Abeta) fibrillization and toxicity. J Biol Chem 287(40):33104-33108

67. Fluharty BR, Biasini E, Stravalaci M, Sclip A, Diomede L, Balducci C, la Vitola P, Messa M et al (2013) An N-terminal fragment of the prion protein binds to amyloid-beta oligomers and inhibits their neurotoxicity in vivo. J Biol Chem 288(11): 7857-7866

68. Scott-McKean JJ, Surewicz K, Choi JK, Ruffin VA, Salameh AI, Nieznanski K, Costa ACS, Surewicz WK (2016) Soluble prion protein and its $\mathrm{N}$-terminal fragment prevent impairment of synaptic plasticity by Abeta oligomers: Implications for novel therapeutic strategy in Alzheimer's disease. Neurobiol Dis 91:124-131

69. Nieznanska H et al (2018) Identification of prion protein-derived peptides of potential use in Alzheimer's disease therapy. Biochim Biophys Acta Mol Basis Dis 1864(6 Pt A):2143-2153

70. Rosener NS et al (2018) A d-enantiomeric peptide interferes with heteroassociation of amyloid-beta oligomers and prion protein. $\mathrm{J}$ Biol Chem 293(41):15748-15764

71. Mengel D, Hong W, Corbett GT, Liu W, DeSousa A, Solforosi L, Fang C, Frosch MP et al (2019) PrP-grafted antibodies bind certain amyloid beta-protein aggregates, but do not prevent toxicity. Brain Res 1710:125-135 
72. Oliveira-Martins JB, Yusa SI, Calella AM, Bridel C, Baumann F, Dametto P, Aguzzi A (2010) Unexpected tolerance of alphacleavage of the prion protein to sequence variations. PLoS One 5(2): 9107

73. Liang J, Kong Q (2012) Alpha-cleavage of cellular prion protein. Prion 6(5):453-460

74. Altmeppen HC, Prox J, Puig B, Dohler F, Falker C, Krasemann S, Glatzel M (2013) Roles of endoproteolytic alpha-cleavage and shedding of the prion protein in neurodegeneration. FEBS $\mathrm{J}$ 280(18):4338-4347

75. Beland M, Roucou X (2014) Taking advantage of physiological proteolytic processing of the prion protein for a therapeutic perspective in prion and Alzheimer diseases. Prion 8(1):106-110

76. Jager $\mathrm{V}$ et al (2013) High level transient production of recombinant antibodies and antibody fusion proteins in HEK293 cells. BMC Biotechnol 13:52

77. Fischer M, Rülicke T, Raeber A, Sailer A, Moser M, Oesch B, Brandner S, Aguzzi A et al (1996) Prion protein (PrP) with aminoproximal deletions restoring susceptibility of PrP knockout mice to scrapie. EMBO J 15(6):1255-1264

78. Kaech S, Banker G (2006) Culturing hippocampal neurons. Nat Protoc 1(5):2406-2415

79. Falker C, Hartmann A, Guett I, Dohler F, Altmeppen H, Betzel C, Schubert R, Thurm D et al (2016) Exosomal cellular prion protein drives fibrillization of amyloid beta and counteracts amyloid betamediated neurotoxicity. J Neurochem 137(1):88-100

80. Danielson E, Lee SH (2014) SynPAnal: software for rapid quantification of the density and intensity of protein puncta from fluorescence microscopy images of neurons. PLoS One 9(12): e115298

81. Ran FA, Hsu PD, Wright J, Agarwala V, Scott DA, Zhang F (2013) Genome engineering using the CRISPR-Cas9 system. Nat Protoc 8(11):2281-2308

82. Livak KJ, Schmittgen TD (2001) Analysis of relative gene expression data using real-time quantitative PCR and the 2(-Delta Delta C(T)) method. Methods 25(4):402-408

83. Altmeppen HC, Prox J, Krasemann S, Puig B, Kruszewski K, Dohler F, Bernreuther C, Hoxha A et al (2015) The sheddase ADAM10 is a potent modulator of prion disease. Elife 4

84. Bueler $\mathrm{H}$ et al (1993) Mice devoid of PrP are resistant to scrapie. Cell 73(7):1339-1347

85. Lewis V, Johanssen VA, Crouch PJ, Klug GM, Hooper NM, Collins SJ (2016) Prion protein "gamma-cleavage": characterizing a novel endoproteolytic processing event. Cell Mol Life Sci 73(3): 667-683

86. Heske J, Heller U, Winklhofer KF, Tatzelt J (2004) The C-terminal globular domain of the prion protein is necessary and sufficient for import into the endoplasmic reticulum. J Biol Chem 279(7):54355443

87. Miesbauer M, Pfeiffer NV, Rambold AS, Müller V, Kiachopoulos S, Winklhofer KF, Tatzelt J (2009) Alpha-helical domains promote translocation of intrinsically disordered polypeptides into the endoplasmic reticulum. J Biol Chem 284(36):24384-24393

88. Cisse $\mathrm{M}$ et al (2011) The extracellular regulated kinase-1 (ERK1) controls regulated alpha-secretase-mediated processing, promoter transactivation, and mRNA levels of the cellular prion protein. $\mathrm{J}$ Biol Chem 286(33):29192-29206

89. Dirndorfer D, Seidel RP, Nimrod G, Miesbauer M, Ben-Tal N, Engelhard M, Zimmermann R, Winklhofer KF et al (2013) The alpha-helical structure of prodomains promotes translocation of intrinsically disordered neuropeptide hormones into the endoplasmic reticulum. J Biol Chem 288(20):13961-13973

90. Hegde RS, Bernstein HD (2006) The surprising complexity of signal sequences. Trends Biochem Sci 31(10):563-571

91. Ziska A, Tatzelt J, Dudek J, Paton AW, Paton JC, Zimmermann R, Haßdenteufel S (2019) The signal peptide plus a cluster of positive charges in prion protein dictate chaperone-mediated Sec61 channel gating. Biol Open 8(3) pii: bio040691)

92. Stewart RS, Harris DA (2003) Mutational analysis of topological determinants in prion protein $(\mathrm{PrP})$ and measurement of transmembrane and cytosolic PrP during prion infection. J Biol Chem 278(46):45960-45968

93. Emerman AB, Zhang ZR, Chakrabarti O, Hegde RS (2010) Compartment-restricted biotinylation reveals novel features of prion protein metabolism in vivo. Mol Biol Cell 21(24):4325-4337

94. Miesbauer M, Rambold AS, Winklhofer KF, Tatzelt J (2010) Targeting of the prion protein to the cytosol: mechanisms and consequences. Curr Issues Mol Biol 12(2):109-118

95. Song Z, Zhao D, Yang L (2013) Metabolism of minor isoforms of prion proteins: cytosolic prion protein and transmembrane prion protein. Neural Regen Res 8(30):2868-2878

96. Godsave SF, Peters PJ, Wille H (2015) Subcellular distribution of the prion protein in sickness and in health. Virus Res 207:136-145

97. Drisaldi B, Stewart RS, Adles C, Stewart LR, Quaglio E, Biasini E, Fioriti L, Chiesa R et al (2003) Mutant PrP is delayed in its exit from the endoplasmic reticulum, but neither wild-type nor mutant $\mathrm{PrP}$ undergoes retrotranslocation prior to proteasomal degradation. J Biol Chem 278:21732-21743

98. Orsi A, Fioriti L, Chiesa R, Sitia R (2006) Conditions of endoplasmic reticulum stress favor the accumulation of cytosolic prion protein. J Biol Chem 281(41):30431-30438

99. Ashok A, Hegde RS (2009) Selective processing and metabolism of disease-causing mutant prion proteins. PLoS Pathog 5(6): e1000479

100. Mironov A Jr, Latawiec D, Wille H, Bouzamondo-Bernstein E, Legname G, Williamson RA, Burton D, DeArmond SJ et al (2003) Cytosolic prion protein in neurons. J Neurosci 23(18): 7183-7193

101. Yedidia Y, Horonchik L, Tzaban S, Yanai A, Taraboulos A (2001) Proteasomes and ubiquitin are involved in the turnover of the wild-type prion protein. EMBO J 20(19):5383-5391

102. Ma J, Wollmann R, Lindquist S (2002) Neurotoxicity and neurodegeneration when $\operatorname{PrP}$ accumulates in the cytosol. Science 298: $1781-1785$

103. Grenier C, Bissonnette C, Volkov L, Roucou X (2006) Molecular morphology and toxicity of cytoplasmic prion protein aggregates in neuronal and non-neuronal cells. J Neurochem 97(5):14561466

104. Wang X, Bowers SL, Wang F, Pu XA, Nelson RJ, Ma J (2009) Cytoplasmic prion protein induces forebrain neurotoxicity. Biochim Biophys Acta 1792(6):555-563

105. Roucou X, Guo Q, Zhang Y, Goodyer CG, LeBlanc AC (2003) Cytosolic prion protein is not toxic and protects against Baxmediated cell death in human primary neurons. J Biol Chem 278:40877-40881

106. Fioriti L, Dossena S, Stewart LR, Stewart RS, Harris DA, Forloni G, Chiesa R (2005) Cytosolic prion protein (PrP) is not toxic in N2a cells and primary neurons expressing pathogenic PrP mutations. J Biol Chem 280(12):11320-11328

107. Restelli E, Fioriti L, Mantovani S, Airaghi S, Forloni G, Chiesa R (2010) Cell type-specific neuroprotective activity of untranslocated prion protein. PLoS One 5(10):e13725

108. Thackray AM, Zhang C, Arndt T, Bujdoso R (2014) Cytosolic PrP can participate in prion-mediated toxicity. J Virol 88(14):8129 8138

109. Chakrabarti O, Hegde RS (2009) Functional depletion of mahogunin by cytosolically exposed prion protein contributes to neurodegeneration. Cell 137(6):1136-1147

110. Chakrabarti O, Ashok A, Hegde RS (2009) Prion protein biosynthesis and its emerging role in neurodegeneration. Trends Biochem Sci 34(6):287-295 
111. Um JW et al (2012) Alzheimer amyloid-beta oligomer bound to postsynaptic prion protein activates Fyn to impair neurons. Nat Neurosci 15(9):1227-1235

112. Um JW, Kaufman AC, Kostylev M, Heiss JK, Stagi M, Takahashi H, Kerrisk ME, Vortmeyer A et al (2013) Metabotropic glutamate receptor 5 is a coreceptor for Alzheimer abeta oligomer bound to cellular prion protein. Neuron 79(5):887-902

113. Fang C, Wu B, le NTT, Imberdis T, Mercer RCC, Harris DA (2018) Prions activate a p38 MAPK synaptotoxic signaling pathway. PLoS Pathog 14(9):e1007283

114. Ma J, Lindquist S (2001) Wild-type PrP and a mutant associated with prion disease are subject to retrograde transport and proteasome degradation. Proc Natl Acad Sci U S A 98(26):14955-14960

115. Kristiansen M, Messenger MJ, Klöhn PC, Brandner S, Wadsworth JDF, Collinge J, Tabrizi SJ (2005) Disease-related prion protein forms aggresomes in neuronal cells leading to caspase activation and apoptosis. J Biol Chem 280(46):38851-38861

116. Kristiansen M, Deriziotis P, Dimcheff DE, Jackson GS, Ovaa H, Naumann H, Clarke AR, van Leeuwen FWB et al (2007) Diseaseassociated prion protein oligomers inhibit the $26 \mathrm{~S}$ proteasome. Mol Cell 26(2):175-188

117. Rane NS, Kang SW, Chakrabarti O, Feigenbaum L, Hegde RS (2008) Reduced translocation of nascent prion protein during ER stress contributes to neurodegeneration. Dev Cell 15(3):359-370

118. Deriziotis P, André R, Smith DM, Goold R, Kinghorn KJ, Kristiansen M, Nathan JA, Rosenzweig R et al (2011) Misfolded PrP impairs the UPS by interaction with the 20S proteasome and inhibition of substrate entry. EMBO J 30(15):30653077

119. McKinnon C, Goold R, Andre R, Devoy A, Ortega Z, Moonga J, Linehan JM, Brandner S et al (2016) Prion-mediated neurodegeneration is associated with early impairment of the ubiquitinproteasome system. Acta Neuropathol 131(3):411-425

120. Rubinsztein DC (2006) The roles of intracellular proteindegradation pathways in neurodegeneration. Nature 443(7113): 780-786

121. Dron M, Dandoy-Dron F, Farooq Salamat MK, Laude H (2009) Proteasome inhibitors promote the sequestration of PrPSc into aggresomes within the cytosol of prion-infected CAD neuronal cells. J Gen Virol 90(Pt 8):2050-2060

122. Goold R, McKinnon C, Tabrizi SJ (2015) Prion degradation pathways: potential for therapeutic intervention. Mol Cell Neurosci 66(Pt A):12-20

123. Puig B, Altmeppen HC, Ulbrich S, Linsenmeier L, Krasemann S, Chakroun K, Acevedo-Morantes CY, Wille H et al (2016) Secretory pathway retention of mutant prion protein induces p38-MAPK activation and lethal disease in mice. Sci Rep 6:24970

124. Le NTT, Wu B, Harris DA (2019) Prion neurotoxicity. Brain Pathol 29(2):263-277

125. Yu C, Nwabuisi-Heath E, Laxton K, LaDu MJ (2010) Endocytic pathways mediating oligomeric Abeta42 neurotoxicity. Mol Neurodegener 5:19

126. Choi JK, Cali I, Surewicz K, Kong Q, Gambetti P, Surewicz WK (2016) Amyloid fibrils from the N-terminal prion protein fragment are infectious. Proc Natl Acad Sci U S A 113(48):13851-13856

127. Wang X, Wang F, Arterburn L, Wollmann R, Ma J (2006) The interaction between cytoplasmic prion protein and the hydrophobic lipid core of membrane correlates with neurotoxicity. J Biol Chem 281(19):13559-13565

128. Lofgren $\mathrm{K}$ et al (2008) Antiprion properties of prion proteinderived cell-penetrating peptides. FASEB J 22(7):2177-2184

129. Soderberg KL et al (2014) Targeting prion propagation using peptide constructs with signal sequence motifs. Arch Biochem Biophys 564:254-261

130. Gomes MP et al (2008) Prion protein complexed to N2a cellular RNAs through its $\mathrm{N}$-terminal domain forms aggregates and is toxic to murine neuroblastoma cells. J Biol Chem 283(28): 19616-19625

131. Kovachev PS, Gomes MPB, Cordeiro Y, Ferreira NC, Valadão LPF, Ascari LM, Rangel LP, Silva JL et al (2019) RNA modulates aggregation of the recombinant mammalian prion protein by direct interaction. Sci Rep 9(1):12406

Publisher's Note Springer Nature remains neutral with regard to jurisdictional claims in published maps and institutional affiliations. 